\title{
Investigating the Effect of Synergistic Glycyrrhiza glabra and Astraglus gossypinus on Improvement of Gastrointestinal Wound in Rats
}

\author{
Mohaddeseh Larypoor*1 ${ }^{(D)}$, Elham Akhavan Sepahy² ${ }^{\text {(D) Anitasadat Tabatabaee Alavi }}$
}

1. Department of Microbiology, Faculty of Biological Sciences, Islamic Azad University, Tehran North Branch, Tehran, Iran

2. Farzanegan 2 Highschool, Tehran, Iran

Background: Due to the increase in gastrointestinal diseases, the use of low-potency herbal medicines for treatment has increased. The synergistic effect of Glycyrrhiza glabra and Astragalus gossypinus on the healing of gastric ulcers is the aim of this study.

Materials \& Methods: The both plants were harvested and extracted. The most appropriate dose for the use of $G$. glabra extract in experiments, $200 \mathrm{mg} / \mathrm{kg} /$ day, was determined by performing writing tests and carrageenan. Then, to create of gastric ulcer in rats, rats were gavaged for 3 days with a dose of $200 \mathrm{mg} / \mathrm{kg} /$ day of dissolved aspirin in $1 \%$ Carbocyte methylcellulose. The groups were treated with dose $200 \mathrm{mg} / \mathrm{kg} /$ day (Concentration of $0.363 \mathrm{mg} / \mathrm{mL}$ ) of both extracts and distilled water for 14 days. Four gastric ulcer rat groups, respectively, received both extracts, G. glabra extract, omeprazole and distilled water as a positive control group, and the fifth group or negative control group Without gastric ulcer received distilled water. After the treatment period, the rats were described and ulcers were examined under microscopic and pathological examination.

Results: Both extracts together $(200 \mathrm{mg} / \mathrm{kg} /$ day) reduced the wound coefficient significantly $(P<0.01)$ compared to the two control groups. The percentage of wound healing was increased than the positive control group (omeprazole) $90.27 \%$ and the negative control group (distilled water) 91.53\%. Pathologic examination confirms microscopic findings.

Conclusion: The statistical evaluation of the results shows that the effects of gastric ulcer as a result of the consumption of G. glabra are very low and valuable $(P<0.01)$. Also, the use of both extracts together is not synergistic.

Keywords: Glycyrrhiza glabra, Astraglus gossypinus, Gastric ulcer

Received: 2020/03/12; $\quad$ Accepted: 2020/04/25; Published Online: 2020/07/20

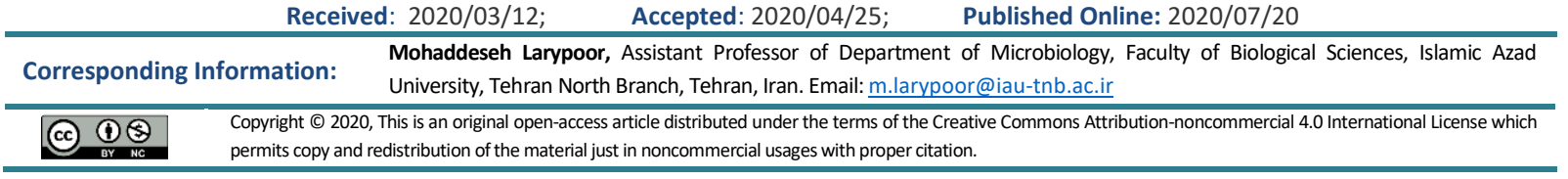

Use your device to scan and read the article online

Larypoor M, Akhavan Sepahy E, Tabatabaee Alavi A. Investigating the Effect of Synergistic Glycyrrhiza glabra and Astraglus gossypinus on Improvement of Gastrointestinal Wound in Rats. Iran J Med Microbiol. 2020; 14 (4) :314-341

\section{Download citation: BibTeX | RIS | EndNote | Medlars | ProCite | Reference Manager | RefWorks}

\section{Send citation to: $\otimes$ Mendeley 2 zotero $\mathbb{H}_{\text {RefWorks }}$}

\section{Introduction}

Licorice with the scientific name of Glycyrrhiza glabra is a plant native to the Mediterranean region and grows in most parts of Iran. This perennial herbaceous plant has numerous underground stems and its leaves are compound. Its flowers are bluish and its fruits contain 5 to 6 rosary-shaped and brown seeds. This plant belongs to the butterfly family and has been one of the most important native medicinal plants in Iran since ancient times, which grows in most regions of Iran. Two varieties named glabra and glandulifera (Waldst \& Kit) Boiss have been identified and the most important collection areas are Fars province. It is widely used in traditional medicine and treatment of digestive problems (1). G. glabra rhizomes contain many active ingredients including triterpene, saponins, glycyrrhizin and 2,4hydroxyglycyrrhizin, which have a sweetening power of 
100-50 times higher than sugar cane. Flavonoids such as isoliquiritigenin liquiritigenin, isolicoflavonol, and isoflavones such as glabren, glabridin, glabrol, 3hydroxyglabrol, and glycyrrhisoflavone are also abundant in this plant root. Other compounds, including hydroxycoumarin include herniarin umbelliferone, glycycoumarin, licopyranocumarin and cumin derivatives, including glycerol, isoglycyrol, liqcoumarin and steroids, including stereos, beta-sterols stigmasterol and fructose oils including anethole, Licorice is found. Licorice has a mild nature in terms of ancient Iranian medicine. The most important newly discovered property of licorice, used in Germany, Europe and the United States, is to treat stomach ulcers and stomach cancer. Licorice rhizome and its components can have beneficial effects in the prevention and treatment of gastrointestinal diseases, especially gastric ulcer, bloating, constipation, tonsillitis and hepatitis. On the other hand, the effects of licorice and its active components on the respiratory system and elimination of cough, asthma, and chest infections have been observed in studies (2).

Today, the anti-cancer effects of some Glycyrrhiza glabra compounds have been identified. Also, the beneficial effects of licorice on the treatment of depression indicate a wide range of capabilities of this plant. Licorice and its active ingredients have a wide range of beneficial antioxidant, anti-inflammatory and anti-allergic effects. Therefore, in Phytotherapy, special attention should be paid to this plant. (5, 6 and25) According to the articles, excessive consumption of licorice causes high blood pressure, so it is better to consume tragacanth to eliminate the blood pressure caused by eating licorice plants to eliminate this complication (7). Khoshnam et al. In 2016 proved in a study that the combination of licorice $(90 \mathrm{mg} / \mathrm{kg}$ ) with LNAME has synergistic effects on lowering blood pressure (8).

Tragacanth with the scientific name of Astraglus gossypinus, is the gum and sap of a plant called Astragalus, which has different species in the form of shrubs or perennial and annual herbaceous plants. This plant has more than 200 species that are mostly grown in steppe and mountainous areas of Iran.

Tragacanth also has a warmer nature. This gum flows spontaneously or usually due to a crack in the stem and dries after a short time, which is collected and marketed in two main forms. The start of operation is usually from late spring to early September. Operators first empty around the stem and then make incisions parallel to the stem (parallel to the phloem) with special blades.

After a few days, the sap (tragacanth) seeps out due to an incision made in the stem, and the sap loses its water and hardens when exposed to sunlight. Operators collect tragacanth twenty days after cutting and repeat the process. In the past, people used tragacanth to wash dry hair. This compound is used to strengthen normal and oily hair and to strengthen dry hair, cough and sputum. Tragacanth contains $10-15 \%$ water, 3-4\% minerals and $3 \%$ starch, and the molecular weight of tragacanth is over eight hundred thousand daltons. Tragacanth is an odorless substance that does not dissolve $60-70 \%$ in water, but by absorbing moisture, it becomes a sticky glaze in which starch particles can be seen.

In tragacanth there are generally two types of significant active substances, one is a substance that is soluble in water called tragacanthine, and the second is a substance that is insoluble in cold water and is called basorin. Tragacanthine is composed of galacturonic acid, which is attached to the sugars galactose and xylose. Basurin also contains galacturonic acid bound to the sugars galactose and xylose. These effective substances prevent the prolongation of the stoppage time of feces in the intestine and ultimately prevent the adverse effects of toxins on intestinal tissue and thus prevent the carcinogenic effects of fecal matter (7). Due to the nativeness, I was cheap and the availability of this herb, these plants can be a good alternative to chemical drugs effective in the treatment of gastric ulcer and have the least side effects after consumption.

Gastric or peptic ulcer is one of the most important diseases in which many people in the community are affected. Gastric or peptic ulcer: It is a painful lesion that occurs on the inner wall of the stomach or at the beginning of the small intestine called the duodenum. No known single cause of gastric ulcer has been found. However, it is now clear that gastric ulcer is the result of an imbalance of gastrointestinal and duodenal fluids. One of the causes of stomach ulcers is an infection caused by a bacterium called Helicobacter pylori. Also, the use of painkillers called nonsteroidal antiinflammatory drugs or NSAIDS, including aspirin, naproxen, ibuprofen and many other drugs can also be effective in treating the symptoms of gastric ulcer (3). Family history of gastric ulcer, other diseases such as liver, kidney or lung diseases, frequent drinking of alcohol and over 50 years of age are also effective in this disease (7).

Some symptoms of stomach ulcers include burning pain in the middle or upper part of the stomach between meals or at night, bloating, heartburn, nausea or vomiting, black or dark stools (due to bleeding), high blood pressure, weight loss, and severe pain. It is in the middle or upper part of the stomach (7).

Half of the people in the community suffer from stomach problems and do not have a proper treatment plan. There are methods for treating stomach ulcers such as antibiotics, endoscopy and surgery. Drugs such as Prilosec, Prevacid, Aciphex, Protonix, Zegerid are used in 
the treatment of gastric ulcers, which have many side effects and are expensive (9).

Providing a suitable herbal medicine can be a good alternative to chemical treatments for this disease and this is very important. In addition, herbal medicines have the least side effects compared to chemical medicines. The use of native medicinal plants can be the cheapest and available to the patient and reduce the cost of importing medicinal plants and chemical drugs.

\section{Materials and Methods}

This study is related to a two-person experimental study of seventh grade students of Farzanegan Two High School under the guidance of Ms. Bozorgzadeh, High School Research Secretary and Dr. Larypoor, an Assistant Professor of the faculty of Islamic Azad University, North Tehran Branch is done.

\section{Evaluation of Effective Doses of Glycyrrhiza glabra}

In order to evaluate the anti-ulcer effects of aqueous extract of Glycyrrhiza glabra, rating and teal flick tests were used. Also, Lorek's method was used to evaluate the acute toxicity of the extract (21). The results of these tests show that the aqueous extract of licorice at a dose of $200 \mathrm{mg} / \mathrm{kg}$ clearly showed the anti-ulcer effect on the writing and tealflick tests. Dad. $(P<0.01)$

\section{Rating Test}

In this experiment, adult male NMRI mice weighing 25-35 g were used and on the day of the experiment, in order to accustom the animals to the environment, each of them was placed in the standard glass box 30 minutes before the start of the experiment. Aqueous extract of Glycyrrhiza glabra was dissolved in sterile saline and injected intraperitoneally at doses of 100, 200 and $300 \mathrm{mg} / \mathrm{kg}$ body weight $(4,22)$. After 15 minutes, acetic acid in a volume of $0.1 \mathrm{ml} / \mathrm{kg}$ was injected at a concentration of $0.6 \%$, and after intraperitoneal injection of acetic acid, the number of abdominal contractions was counted for 30 minutes. In addition, each animal was used only once in the control group, after intraperitoneal injection of saline, a rating test was performed (21-23).

\section{Carrageenan test}

To perform the carrageenan test, first, adult male NMRI mice weighing 25-35 g in seven groups were treated with the desired substance (saline, extract, dexamethasone) in the amount of $0.2 \mathrm{~mL}$ intraperitoneally. One hour later, $0.1 \mathrm{~mL}$ of $1 \%$ carrageenan was injected subcutaneously into the dorsal surface of the animal's right foot. Four hours after carrageenan injection, mice were killed by chloroform and their legs were amputated. Inflammation index was assessed (24). All data were statistically analyzed using one-way ANOVA and Tukey test. Results were presented as a mean \pm standard deviation (S.E.M \pm Mean). The criterion for statistical inference is $(P<0.05)$ (24).

\section{Preparation of Medicinal Plant}

The root of licorice identified with the number IAUNT17333 was prepared from the herbarium of Islamic Azad University, North Tehran Branch and after cleaning, it was divided into $1 \mathrm{~cm}$ pieces and ground. It was then poured onto a cloth and $300 \mathrm{~mL}$ of $70 \%$ methanol was poured into a Soxhlet balloon. After 24 hours, the solvent was gradually evaporated by heat and the active ingredients were transferred to the solvent. The extract was then filtered and transferred to a rotary apparatus at $45^{\circ} \mathrm{C}$ and $45^{\circ} \mathrm{C}$ for one hour to separate the solvent. The extract was then transferred to a dark container and stored in the refrigerator for subsequent experiments $(10,3)$.

Edible tragacanth with the number IAUNT17334 was prepared from the herbarium of Islamic Azad University, North Tehran Branch, and after powdering, it was dissolved in sterile distilled water at a temperature of $45^{\circ} \mathrm{C}$ and used. In this study, based on the rating test, carrageenan and determination of toxicity dose and also based on the results of research of Sepehri et al. (2007), the dose of these two herbal medicines was determined to be $200 \mathrm{mg} / \mathrm{kg}$. $(4,22)$ All solutions were stored at $4^{\circ} \mathrm{C}$ for later use.

\section{(LD50) Determination of Acute Toxicity}

This test was performed based on the method of Dietrich Lorke (1983) (21). After intraperitoneal injection of dilutions of the extract at doses of 10,100, $1000,1600,2900$ and $5000 \mathrm{~kg} / \mathrm{mg}$, the mortality rate (LD50) of $50 \%$ of mice up to 72 hours after injection was evaluated.

\section{The Effect of Aqueous Extract of Glycyrrhiza glabra and Tragacanth in vivo}

31 NMRI rats weighing 200-230 g were obtained from Pasteur Institute of Iran. The animals were kept in cages with long mesh floors to prevent defecation and at a temperature of $22-25^{\circ} \mathrm{C}$ and a period of light and darkness for 12 hours and were fed with normal food and free access to water. In order to empty the stomach, all animals except the negative control were kept hungry for 48 hours and fed with $8 \%$ sucrose solution during the starvation period to avoid dehydration. Then 4 groups of mice were gavaged for 3 days with aspirin at a dose of $200 \mathrm{mg}$ dissolved in $1 \mathrm{cc}$ of solvent ( $1 \%$ carboxymethylcellulose) based on daily weight of mice. The absence of halal wound healing effect has already been confirmed $(3,4)$.

Depending on the type of treatment for 14 days, each group received a veterinary licorice extract (concentration 
of $0.036 \mathrm{mg} / \mathrm{mL}$ per compound) and distilled water at a dose of $200 \mathrm{mg}$ by gavage $(10,19)$. These mice were classified into five groups and each group had 6 mice and were treated for two weeks. The experimental groups were:

1- The first group of mice with gastric ulcer that were treated with licorice extract of Tragacanth at a dose of $200 \mathrm{mg}$ based on daily weight of mice.

2- The second group of mice with gastric ulcer that were treated with licorice extract at a dose of $200 \mathrm{mg}$ based on daily weight of mice.

3- The third group of mice with gastric ulcer that were treated with omeprazole at a dose of $200 \mathrm{mg}$ based on daily weight of mice.

4- The fourth group or positive control of mice with gastric ulcer that were treated with distilled water at a dose of $200 \mathrm{mg}$ based on daily weight of mice.

5. The fifth group or negative control who did not have gastric ulcer and were treated with distilled water at a dose of $200 \mathrm{mg}$ based on daily weight of rats.

A rat was diagnosed with a gastric ulcer after a period of aspirin administration and was sent to a pathology laboratory for gastric ulcer confirmation. The manner of gavage in different groups is shown in Figure 1.

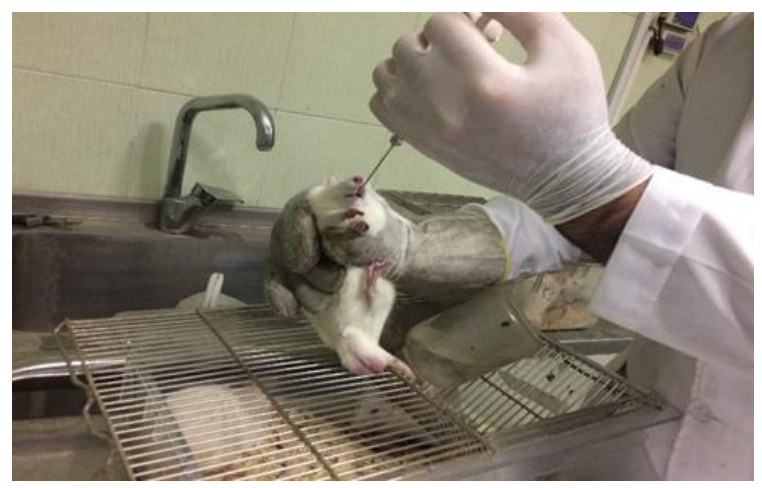

Figure 1. How to gavage extracts in mice

Three hours after the last injection, animals in all groups were killed and their incoming stomach was quickly removed and cut from a large curvature, and then the pathologist examined the type of wound, bleeding, and inflammation. After preparing paraffin sections, the samples were observed with a stereomicroscope (Lica Zoom 2000). Incoming gastric lesions were examined separately and measured using $\mathrm{mm}$ using Wild Heerbrugg, Switzerland (Graticule) and their mean was determined. Spotted lesions (petechiae) with a size of one $\mathrm{mm}$ were also counted and all five spotted lesions were considered as one $\mathrm{mm}$ wounds.

$$
\begin{aligned}
& 1-2=2 \mathrm{~mm} \\
& 3-4=3 \mathrm{~mm} \\
& 6-5=4 \mathrm{~mm}
\end{aligned}
$$

Losses larger than $6 \mathrm{~mm}$ were considered equal to 5 . The sum of the total amount obtained for wounds was calculated and considered as the wound coefficient $(3,11)$. The recovery coefficient was calculated from the following formula:

Healing coefficient $=100 \%$ Wound control coefficient / Treatment wound coefficient - Wound control coefficient

After microscopic calculations, the stomachs and intestines were placed in the neutral formalin buffer and stabilized and prepared for tissue sections. Six-micron sections were prepared and stained by hematoxylin-eosin method and given to the pathologist for interpretation blindly without knowing the tested groups. Microscopic images were taken with the Olympus $\mathrm{CH} 30$ camera and microscope, and macroscopic images were taken directly with the digital camera.

\section{Statistical Analysis}

The results were analyzed by one-way Anovoa test using SPSS 11 software and the difference was considered significant with $\mathrm{P}$-value $<0.01$.

\section{Results}

\section{Acute toxicity results}

According to the results of Table 1, injection of the aqueous extract of Glycyrrhiza glabra (AEGg) in the mentioned doses did not show any acute toxicity. The

\begin{tabular}{|c|c|c|c|}
\hline \multicolumn{2}{|c|}{ The second stage of the acute toxicity test } & \multicolumn{2}{|c|}{ The first step of the acute toxicity test } \\
\hline Dosage and substance & Number of animals / mortality & Dosage and substance & Number of animals / mortality \\
\hline AEGg $1600 \mathrm{mg} / \mathrm{kg}$ & $11 \cdot /$ & $\mathrm{AEGg} 10 \mathrm{mg} / \mathrm{kg}$ & $3 \cdot /$ \\
\hline AEGg $2900 \mathrm{mg} / \mathrm{kg}$ & $11 \cdot /$ & AEGg $100 \mathrm{mg} / \mathrm{kg}$ & $3 \cdot /$ \\
\hline AEGg5000 mg/kg & $11 \cdot /$ & AEGg $1000 \mathrm{mg} / \mathrm{kg}$ & $3 \cdot /$ \\
\hline
\end{tabular}
results are shown in Table 1.

Table 1. Results of acute toxicity determination and evaluation of LD50

$\mathrm{LD}_{50}>5000 \mathrm{mg} / \mathrm{kg}$ / Aqueous extract of Glycyrrhiza glabra (AEGg) 


\section{Rating Test Results}

The results of this test showed that injections of 100, 200 and $300 \mathrm{mg} / \mathrm{kg}$ of aqueous extract of G. glabra decreased compared to the control group, but the dose of $200 \mathrm{mg} / \mathrm{kg}$ showed a significant decrease compared to other treatment groups $(P<0.01)$. Therefore, the dose of $200 \mathrm{mg} / \mathrm{kg}$ was selected for further experiments. The results of this test are shown in Figure 1. As shown in Figure 2, the addition of tragacanth at a dose of $200 \mathrm{mg} / \mathrm{kg}$, which, according to the articles is the best dose for the treatment of gastric ulcer, shows a significant decrease compared to the control group, but this decrease compared to the group receiving aqueous extract of $G$. glabra at a dose of 200 and 300 does not show a significant difference.

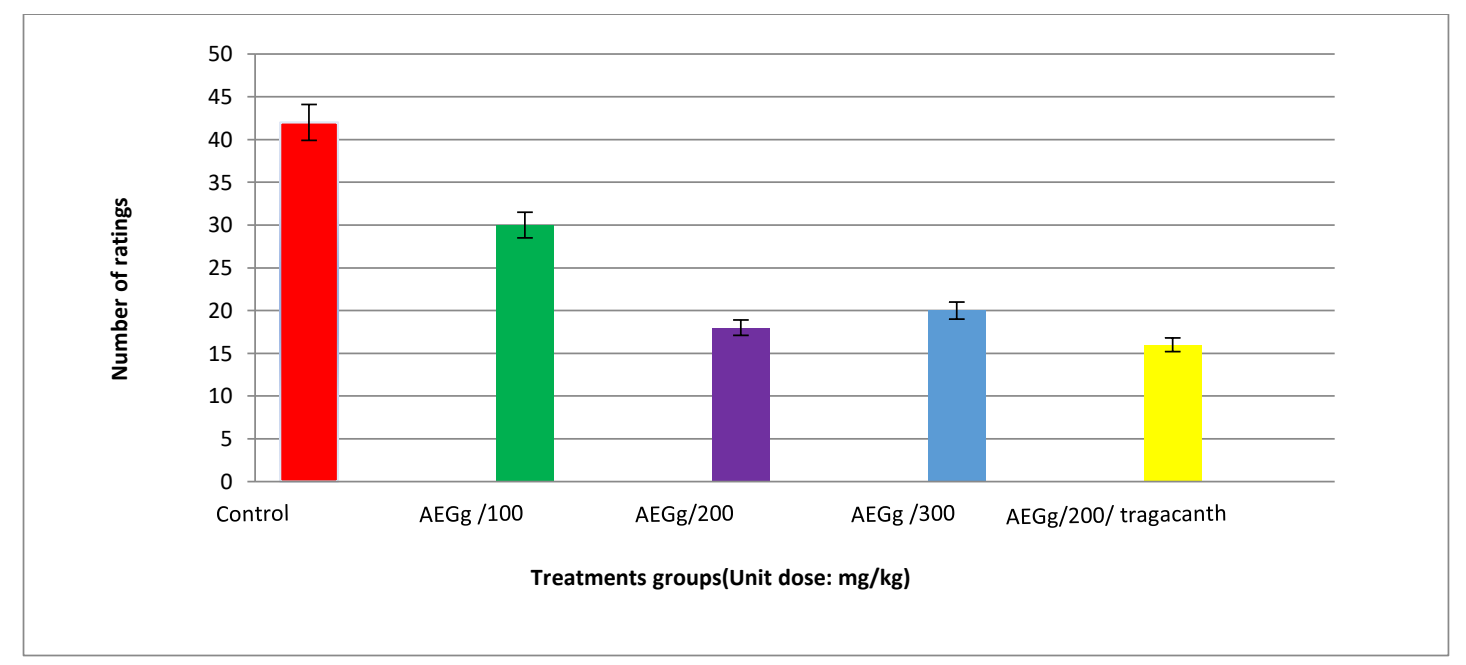

Figure 2. Comparison of mean rat ratings with different concentrations of Aqueous extract of Glycyrrhiza glabra (AEGg) in acetic acid test $(P<0.01)$

\section{Carrageenan Test Results}

In this test, the anti-inflammatory effect of aqueous extract of G. glabra on carrageenan-induced edema in adult male rats in seven groups was investigated. Aqueous extract of G. glabra was injected intraperitoneally at doses of 100, 200 and $300 \mathrm{mg} / \mathrm{kg}$ body weight and dexamethasone at doses of $10 \mathrm{mg} /$ kg body weight. The results were presented as a mean \pm standard deviation in Table 2. P-value $<0.001$ and $P$-value $<0.05$ indicate the difference with the control group.

Table 2. Evaluation of the anti-inflammatory effect of aqueous extract of Glycyrrhiza glabra on carrageenan-induced edema in adult male rats

\begin{tabular}{|c|c|}
\hline Group & Weight difference between right and left foot \\
\hline Control & $3.79 \pm 59$ \\
\hline Witness & $3.50 \quad \pm 60$ \\
\hline Root extract $(100 \mathrm{mg} / \mathrm{kg}$ body weight) & ${ }^{*} 15 / 2 \pm 11 / 58$ \\
\hline Root extract $(200 \mathrm{mg} / \mathrm{kg}$ body weight) & ${ }^{* * *} 84 / 2 \pm 50 / 18$ \\
\hline Root extract (300 $\mathrm{mg} / \mathrm{kg}$ body weight) & ${ }^{* * *} 88 / 0 \pm 32$ \\
\hline Dexamethasone & ${ }^{* * *} 73 / 1 \pm 33 / 10$ \\
\hline
\end{tabular}

*** Significant difference with control and control group $(P<0.001), *$ Significant difference with control and control group $(P<0.05)$

The results of the present study showed that the treatment of aqueous extract of G. glabra, G. glabra on carrageenan-induced edema at doses of 100, 200, $300 \mathrm{mg} / \mathrm{kg}$ body weight and dexamethasone at a dose of $10 \mathrm{mg} / \mathrm{kg}$ body weight, significantly reduced the rate of edema. The animal shows feet compared to the control group. The results of the present study showed that the treatment of licorice at a dose of 200 $\mathrm{mg} / \mathrm{kg}$ body weight caused a significant change in the rate of edema in the animal compared to the control and control groups and even the rate of edema in mice that They have received doses of 100 and $300 \mathrm{mg} / \mathrm{kg}$, 
this difference in edema is more significant and therefore is chosen as the most appropriate dose for subsequent tests, because carrageenan causes edema and as a result, weight gain in the right leg and inflammation.

\section{Pathological Examination Results}

Receiving three consecutive doses of aspirin could cause mucosal lesions in the stomach of mice treated with mucosal lesions and cause bleeding inflammation in the intestine. On macroscopic examination, multiple hemorrhagic lesions of various sizes were observed in the gastric endocrine glands, covering a large portion of the rat gastric gland. On microscopic examination, obvious wounds were seen passing through the mucosal layer and destruction of the epithelial tissue in the entrance stomach. As seen in Figure 3, in the negative control sample of the stomach, the mucosal layer of the gastric mucosa and muscle has a regular and normal appearance and histologically the epithelial and pores are completely healthy. Pathological images of normal rat stomach tissue are shown in Figure 3.
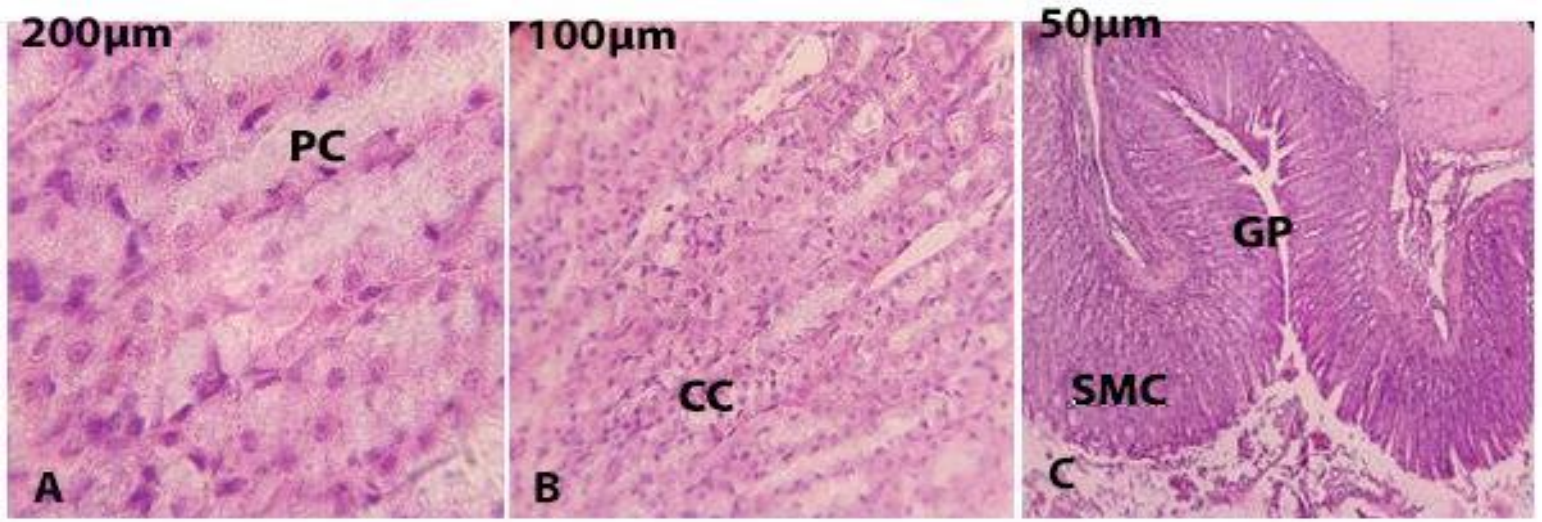

Figure 3. Observation of regular, normal and perfectly healthy appearance of rat gastric epithelial lining as a negative control, PC: gastric wall cells, SMC: superficial mucosal cells, CC: main gastric cells, GP: gastric glands

Figure 4 shows histopathological changes in the gastric tissue of aspirin-treated mice compared to normal gastric tissue. As can be seen in the pictures, the epithelial lining is completely destroyed and the inflammatory cells and lymphocytes are completely visible and the gastric glands are destroyed. The mucosal area of the mucosal minister is completely inflamed. Edema, bleeding and dilation of blood vessels in the stomach are observed.
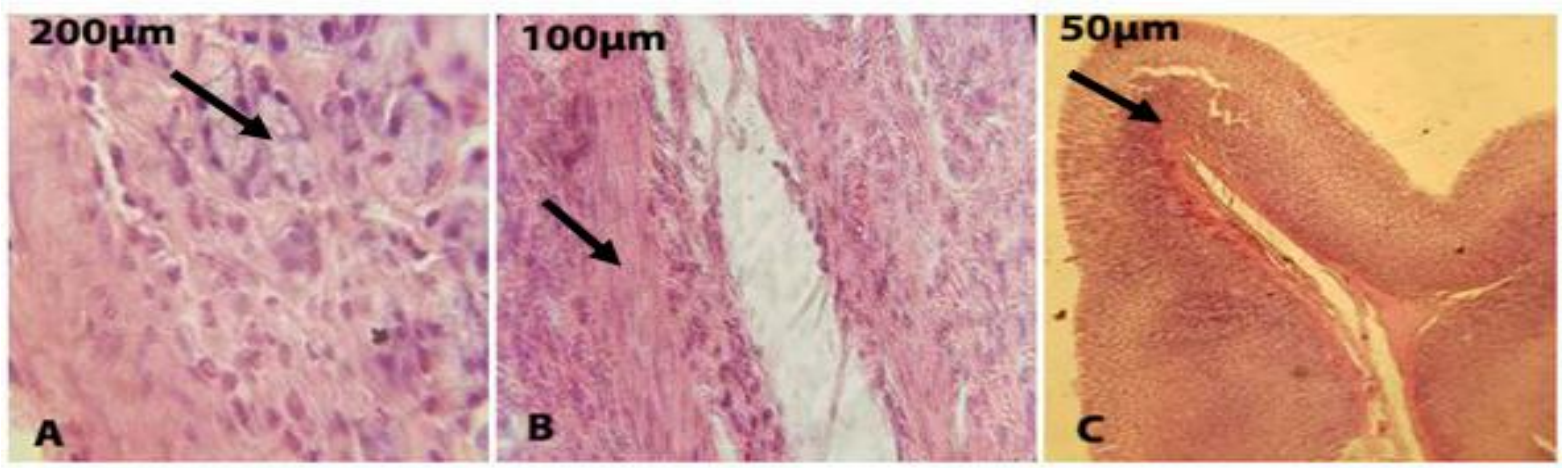

Figure 4. Observation of rat gastric ulcer in comparison with Figure 3: Completely destroyed epithelium (B) and destruction of the endocrine glands (GP) and gastric epithelium (PC) in Figures (A) and (B) are quite evident

In the negative and normal control sample of rat intestine, villi appearance is observed in the surface layer of the intestine, which is completely regular, the muscular layer of the muscle minister and the normal intestinal gland. The stained cross section of a normal rat intestine is shown in Figure 5 . In the positive histopathological specimen of the intestine, inflammation and lymphocyte proliferation in the stained tissue section are quite evident. Increased inflammatory cells such as neutrophils are seen in multiple ducts of the intestinal lining. Lymphocytes are found in the superficial villi of the intestine along with a medium-sized microvacuum with complete edema. Figure 6 shows the inflamed intestinal tissue as a positive control 


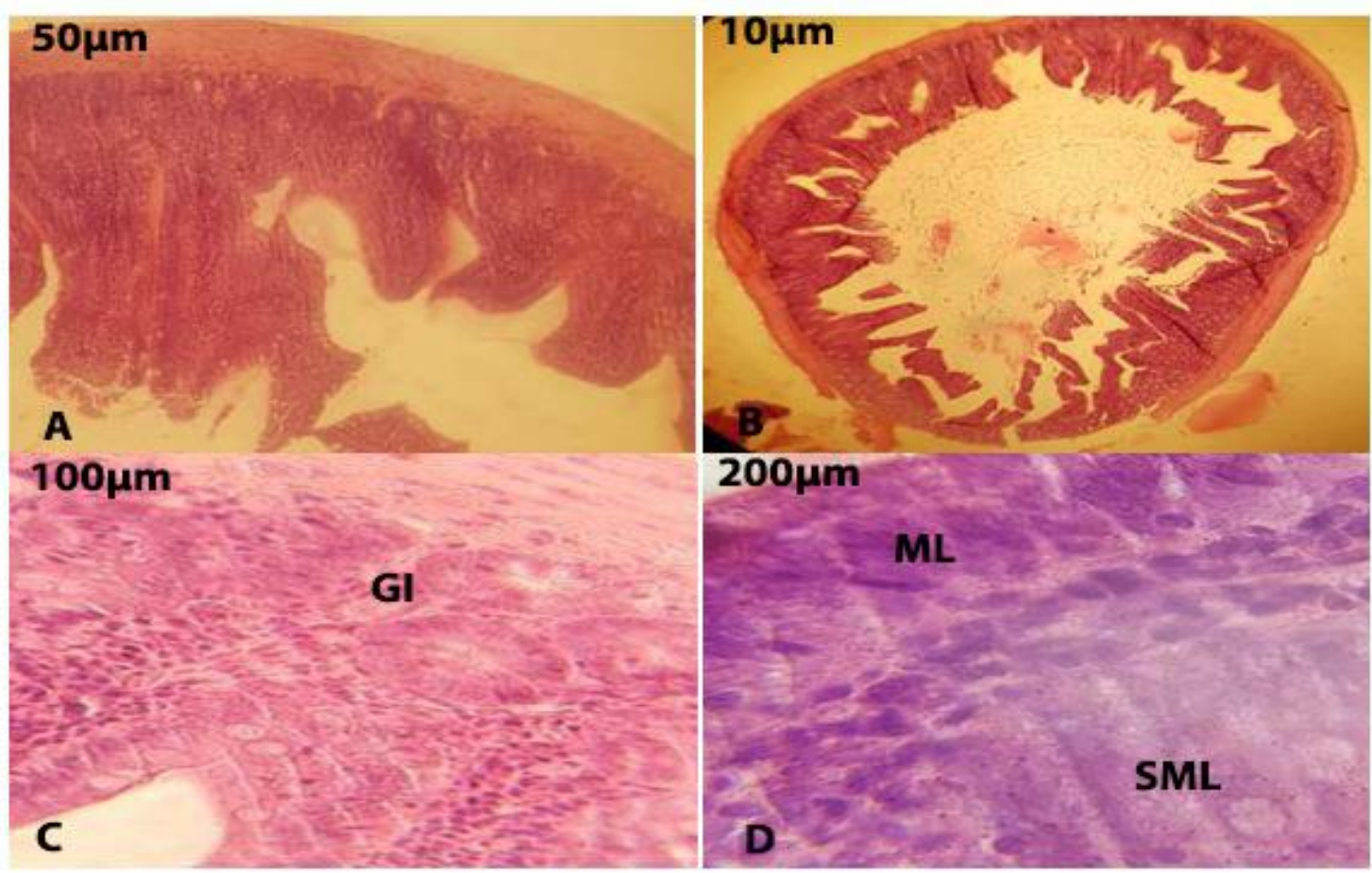

Figure 5. Observation of normal intestinal tissue of mice as a negative control is clearly shown in section (C) of the intestinal glands (GI)

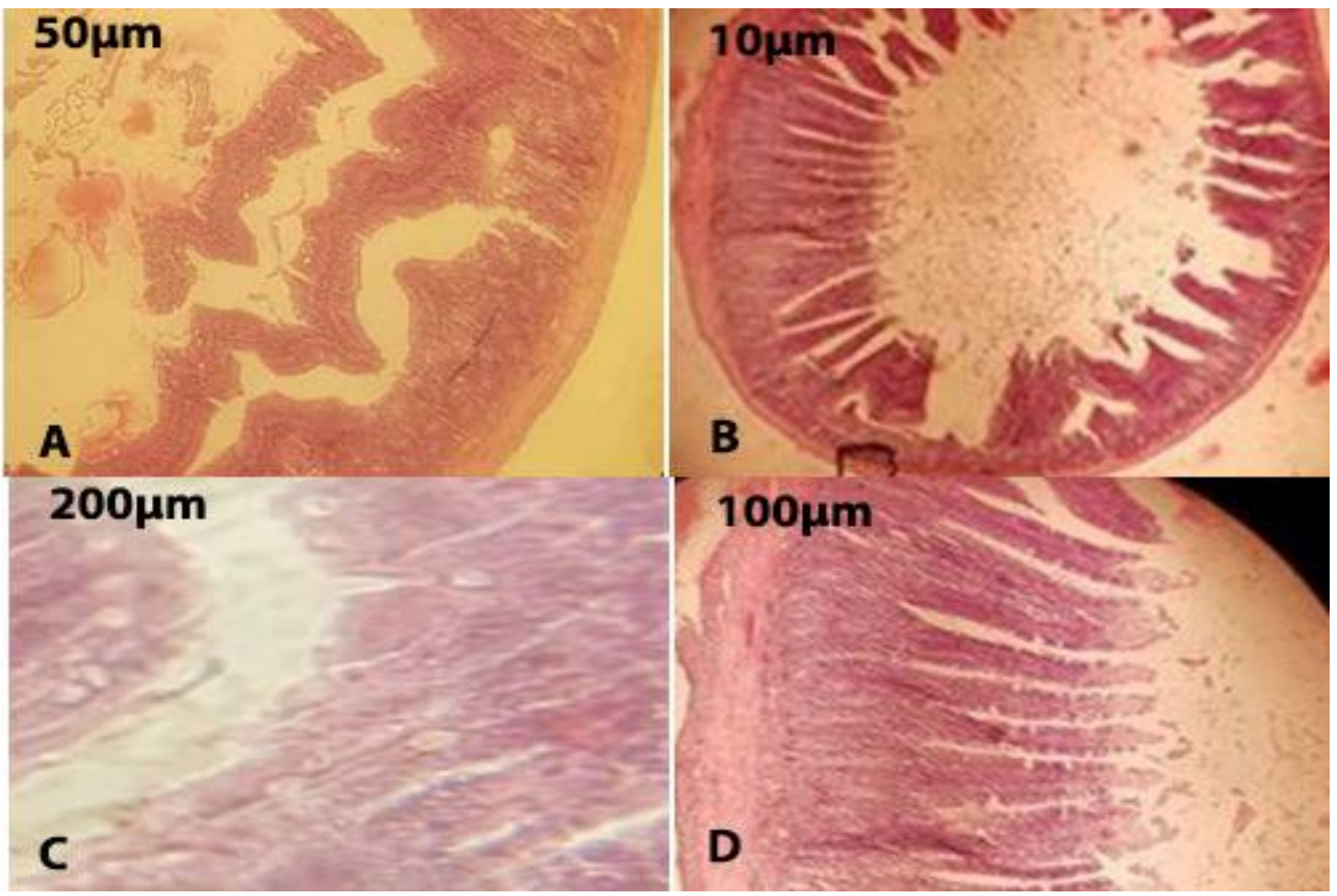

Figure 6. Observation of intestinal inflammation in rats or positive intestinal control under the influence of aspirin (a) Observation of intestinal periphery and an increase in inflammation (C), (D) Specific inflammation and leukocyte secretion in multiple canals and edema have been observed at the surface of epithelial cells at the site of the arrows

In the group receiving licorice, in comparison with the control group of gastric ulcers, the gastric mucosal area is seen as completely normal and compared to the control group of gastric ulcers, only slight blood diffusion and slight neutrophil secretion are seen. The positive effect of aqueous extract of $G$. glabra on 
improving the quality of pathological lesions was also observed, but it had less effect than the stomach. Figure 7 shows the effect of aqueous extract of $G$. glabra on gastric ulcer and Figure 8 shows the effect of aqueous extract of $G$. glabra on intestinal ulcer.
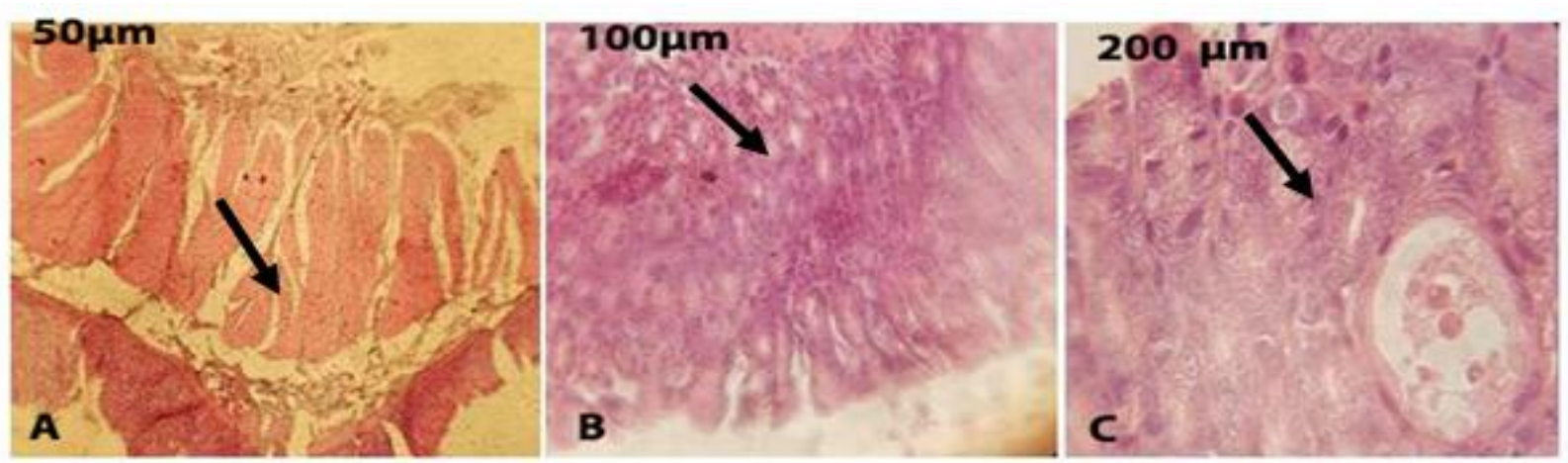

Figure 7. Effect of aqueous extract of G. glabra on gastric ulcer. In Figure (b), the amount of inflammation is reduced compared to the ulcer control sample and the histological structure is completely normal, but a slight exudation of neutrophil cells is observed at the flash.
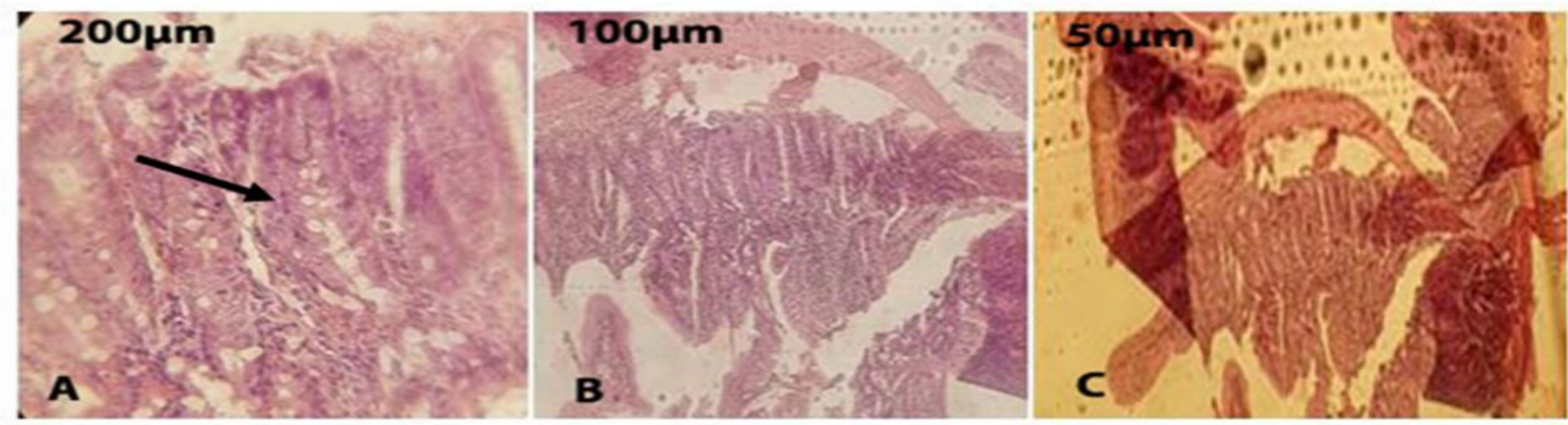

Figure 8. The effect of aqueous extract of G. glabra on intestinal ulcers is shown. The accumulation of blood cells in the intestinal villi is observed at the flash and the spread of inflammatory cells is observed at the tip of the intestines.

As shown in Figure 8, based on pathological studies, in the group receiving aqueous extract of G. glabra in the intestine, mild diffusion of lymphocytes in the submucosal and mucosal region with mild necrosis and inflammation at the tip of the intestinal villi was seen, indicating less effect of licorice on intestinal tissue than It has a beneficial effect on gastric ulcer, but it has significantly reduced the severity of inflammation compared to the positive intestinal control group.

Pathological examinations and calculation of wound coefficient showed that aqueous extract of G. glabra significantly reduced wound coefficient compared to the control group. This lower wound coefficient was also shown in the group receiving tragacanth and aqueous extract of $G$. glabra $(\mathrm{P}<0.01)$.

Also, in the group receiving the aqueous extract of Glycyrrhiza glabra, the wound healing percentage compared to the negative control group (distilled water) was $9.53 \%$ and in the group receiving omeprazole was $90.27 \%$. Also, in the group receiving the composition of licorice extract and veterinary, there was no significant difference in wound healing rate compared to the group receiving licorice alone, while it had almost the same effect on increasing the wound healing percentage. $(P>0.05)$ The results of the wound coefficient are consistent with the pathology results. In pathological examinations in the group receiving the aqueous extract of G. glabra in the stomach, gastric mucus was completely normal and mild lymphocyte proliferation and less bleeding were observed than in the control group, which indicates the positive effect of aqueous extract of G. glabra on wound healing. In the positive control group, the wound healing ratio with omeprazole was $69 \%$, which was lower than the groups receiving the aqueous extract of G. glabra and aqueous extract of $G$. glabra with tragacanth groups. Morphometric evaluation to measure wound spread showed that the wound coefficient in the control groups of distilled water and omeprazole decreased less to the other two treatment groups. The results are shown in Table 3 and Figure 9. In Figure 10, the percentage of wound healing in the treatment groups is compared. 
Table 3. Comparison of aspirin-induced macroscopic wound coefficient in treatment groups and wound healing ratio

\begin{tabular}{|cccc|}
\hline Groups & $\begin{array}{c}\text { Ulcer } \\
\text { Index }\end{array}$ & $\begin{array}{c}\text { Recovery ratio compared to } \\
\text { omeprazole }\end{array}$ & Recovery ratio compared to distilled water \\
\hline AEGg & 2.95 & $90.27 \%$ & $91.53 \%$ \\
\hline AEGg+Tragacanth & 3.2 & $91.85 \%$ & $93.12 \%$ \\
\hline $\begin{array}{c}\text { Omeprazole } \\
\text { (Positive Control) }\end{array}$ & 20.44 & - & $69 \%$ \\
\hline $\begin{array}{c}\text { Distilled Water } \\
\text { (Negative Control) }\end{array}$ & 32.38 & - & 0 \\
\hline
\end{tabular}

Aqueous extract of Glycyrrhiza glabra(AEGg)

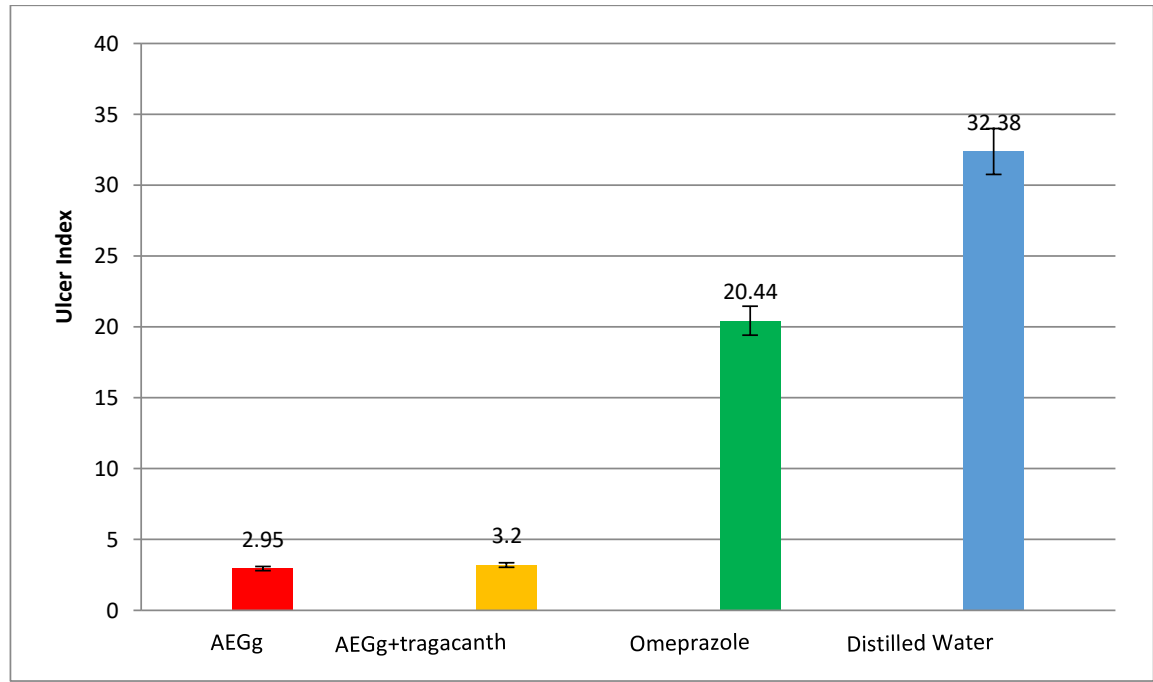

Figure 9. Comparison of wound coefficient in the treatment groups compared with control groups $(P<0.01)$

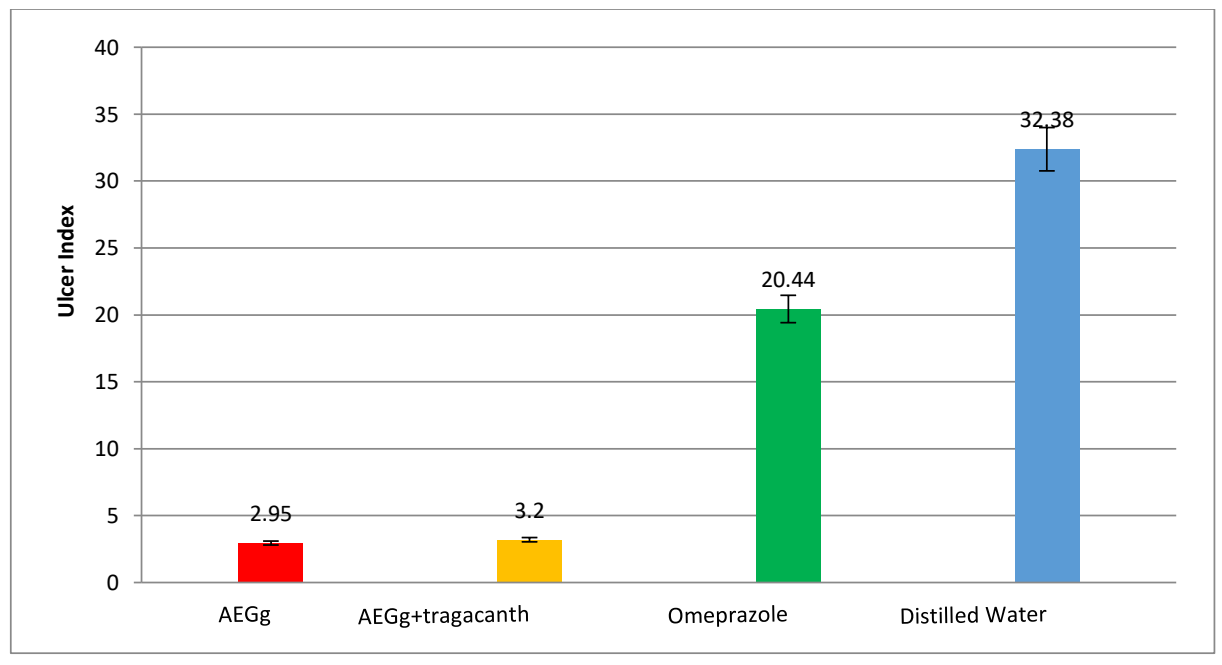

Figure 10. Comparison diagram of recovery percentage in the treatment groups compared with control groups $(P<0.01)$

In the treatment group of aqueous extract of G. glabra and tragacanth, the pathological changes in the stomach completely disappear and the histopathological pattern is completely normal, which shows the synergistic effect of tragacanth and aqueous extract of G. glabra. It is seen at the tips of the villi, which is associated with an increase in polymorphonuclear cells. Mild diffusion of lymphocytes is seen in the submucosa and mucosa, which is a sign of very mild inflammation, but there is mild necrosis in the tips of the villi, which compared to the positive control group, the synergistic effect of tragacanth and aqueous extract of G. glabra in improving inflammation is quite evident. The results are shown in Figures 11 and 12 . 


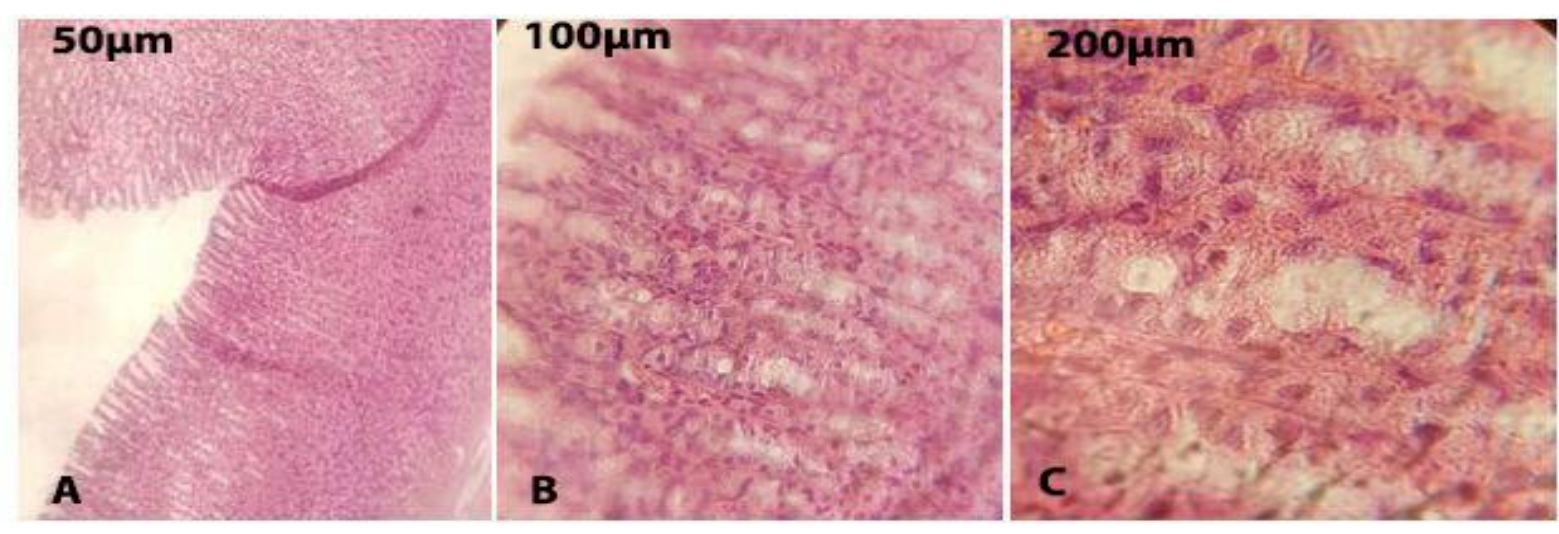

Figure 11. Effect of aqueous extract of G. glabra and tragacanth detoxification of gastric tissue. According to the figure above, the histopathological pattern is completely normalized
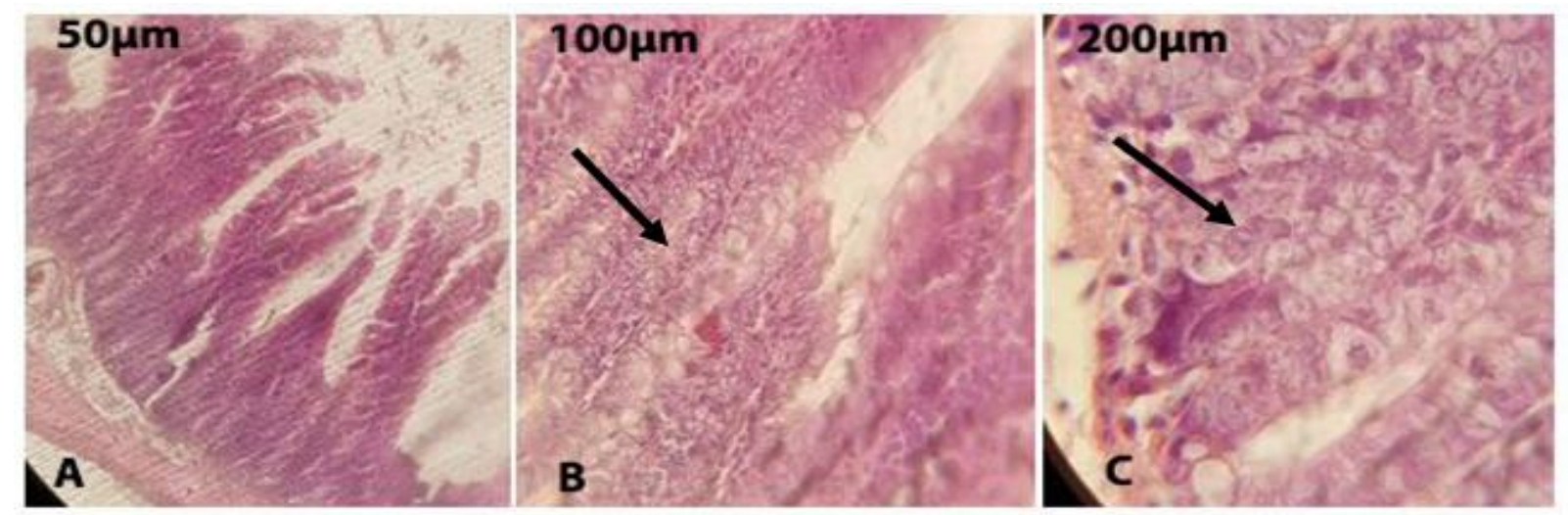

Figure 12. Effect of aqueous extract of G. glabra and veterinary detoxification on intestinal tissue. Mild inflammation and necrosis of a number of lymphocyte (PMN) cells are still seen at the site of Willy swelling after consuming the aqueous extract of G. glabra.

In the omeprazole group, no swelling was seen in the epithelial cells. Regular muscle mass was seen, but lymphocytes were still seen in the submucosal layer, indicating that omeprazole did not heal $100 \%$ of gastric ulcer. The results of the effect of omeprazole on gastric and intestinal tissues are shown in Figures 13 and 14 , respectively.

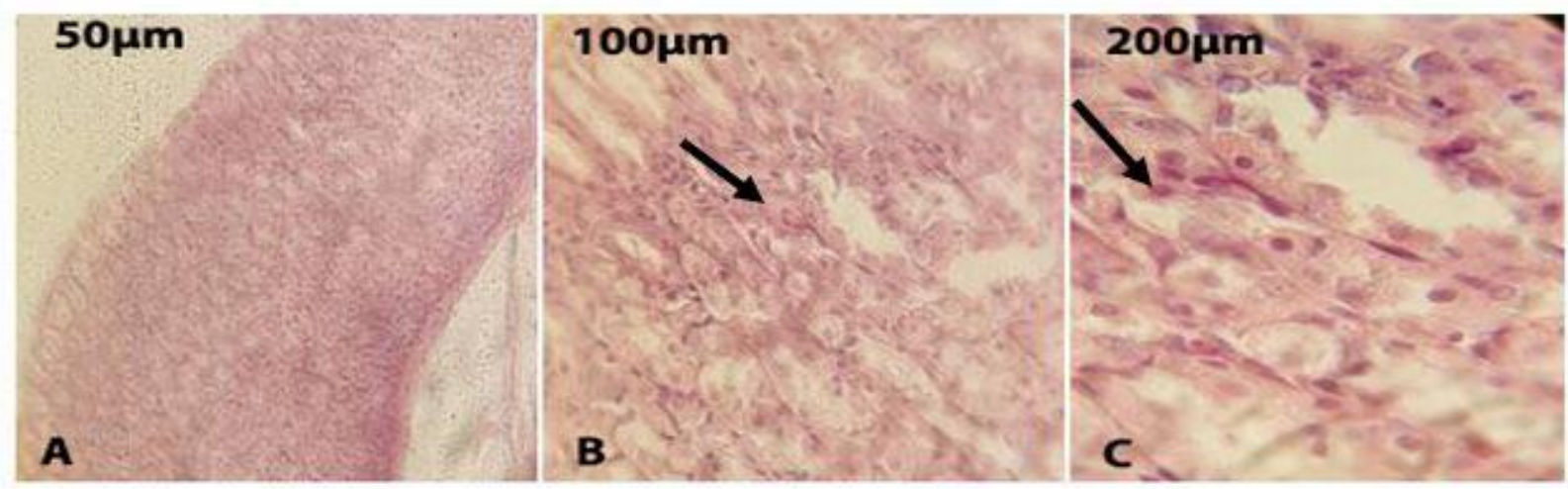

Figure 13. Microscopic picture of pathological ulcer in the stomach in the omeprazole treatment group (Flash: shows a slight lymphocyte infiltration, indicating that the omeprazole treatment does not improve $100 \%$ ). 

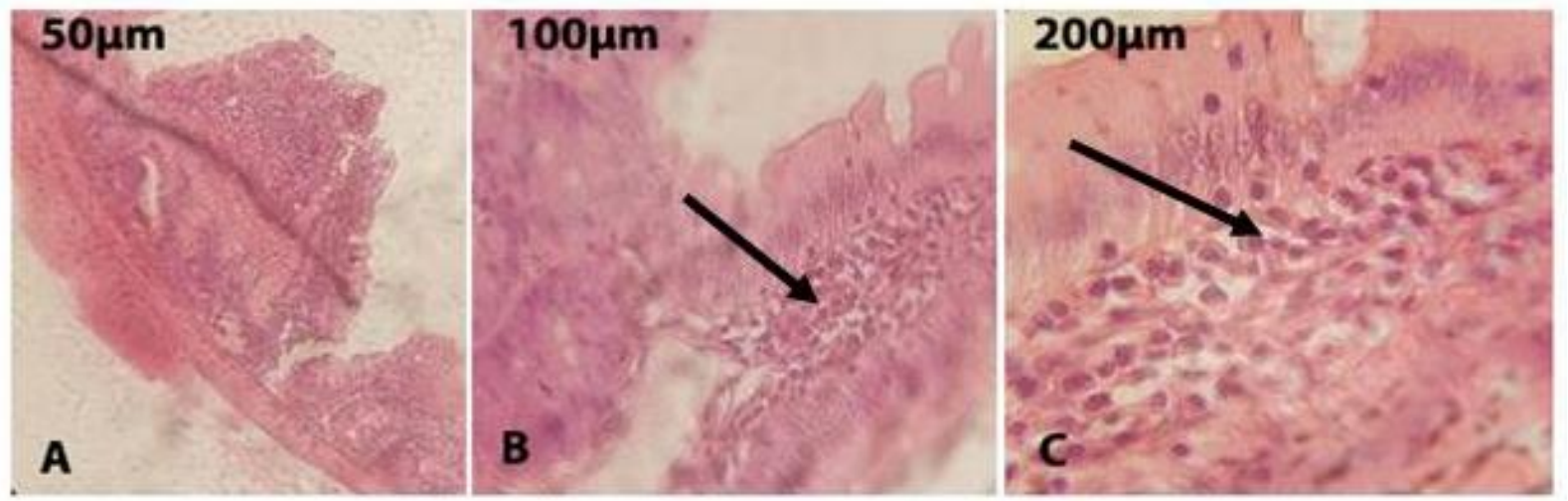

Figure 14. Microscopic picture of pathological ulcer in the intestine in the omeprazole treatment group (flash: shows high neutrophil infiltration with dilation of blood vessels in the intestinal villi, indicating a percentage reduction in improvem ent as a result of omeprazole treatment).

\section{Discussion}

Aqueous extract of Glycyrrhiza glabra $(200 \mathrm{mg} / \mathrm{kg}$ ) has anti-ulcer protective activity in the stomach and anti-inflammatory properties in the intestine and significantly reduces the wound coefficient compared to the two groups of negative control (distilled water) and positive control (omeprazole) $(P<0.01)$ decreases. It also improves wound healing rate compared to $90.27 \%$ positive group and $9.53 \%$ negative control group. Diagnosis of acute toxicity of various unknown compounds, including aqueous extract of Glycyrrhiza glabra, was evaluated using LD50. In fact, the LD50 is an important indicator for detecting the minimum allowable dose in order to kill $50 \%$ of the animals (23, 25). In the present study, no mortality occurred after 72 hours after injection of different doses of the extract, so it is possible that the aqueous extract of Glycyrrhiza glabra is completely safe and harmless in both stages of acute toxicity testing, at least in doses between 10 and $5000 \mathrm{mg} / \mathrm{kg}$. Rating test is used to identify environmental mechanisms and acetic acid used in this test can activate endogenous compounds such as bradykinin, serotonin, histamine.

The results showed that the aqueous extract of Glycyrrhiza glabra prevented abdominal contractions caused by acetic acid. Therefore, a possible cause of the anti-inflammatory and anti-infiltration effect of neutrophils, the extract may be due to inhibition of the release of endogenous compounds (arachidonic acid metabolites) and it is speculated that its sedative effects are supported by environmental mechanisms (23). The results of the present study showed that the aqueous extract of licorice root at a dose of $200 \mathrm{mg} /$ $\mathrm{kg}$ was able to reduce the inflammation induced by carrageenan and rating tests, whose antiinflammatory effect was not comparable to dexamethasone. Aqueous extract of Glycyrrhiza glabra contains glycyrrhizin, liquoricidine, saponin, glycyrrhizic acid, a toxic glycyrrhizin, lactic acid, which, according to current sources suggest that a phenolic substance called glycyrrhizin, which is one of the main constituents of licorice, It has a positive effect on inflammation caused by gastric ulcer in rats and has caused its partial treatment (18).

This is probably due to a change in the antioxidant activity of the plant, which has reduced inflammation by inhibiting protein kinase $C$, phospholipase $A$ and phosphodiesterase, as well as other inflammatory factors such as prostaglandins and histamine $(16,25)$.

Factors such as gastric ulcers enter the body through mechanisms that increase calcium and free radicals, and in the process leading to the release of arachidonic acid and the enzyme cyclooxygenase, which converts it into a prostaglandin precursor, which in turn causes inflammation. The results of the present study show that the aqueous extract of Glycyrrhiza glabra inhibits inflammation in the rating test and carrageenan, but more research is needed to determine the exact mechanisms of their effect and possible pathways of anti-inflammatory action $(23,24)$.

In the study of Jalilzadeh-amin et al. (2015), alcoholic extract of licorice with a dose $(50-150 \mathrm{mg} /$ $\mathrm{kg}$ ) was able to show the anti-ulcer effects of gastric ulcer, which differs from the dose used in this study. Of course, the results of this study are consistent with the results of the present study regarding the percentage of wound healing, but due to the use of ethanolic extract in Jalilzadeh's research on reducing the inflammatory effects differ from the results of this study, because in this study aqueous extract was used and ethanol effect. As a separate parameter, it could be effective in reducing the rate of inflammation. On the other hand, the dose of $200 \mathrm{mg} / \mathrm{kg}$ was given as peritoneal injection, but in this study, the dose was 
used as a gavage and was directly related to intestinal and gastric cells. The place has been effective, which of course requires more research (12). In the microbiological studies, there was no significant difference between the results obtained in the group that received an aqueous extract of Glycyrrhiza glabra and tragacanth together with the group that received only aqueous extract of Glycyrrhiza glabra ( $P>0.05)$, but in the pathological studies, this difference was significant. This result indicates that the association of tragacanth with aqueous extract of Glycyrrhiza glabra is not only effective in relieving histopathological symptoms in the stomach and intestines to some extent, but also according to articles can reduce the side effects of licorice consumption such as high blood pressure. Proves the superiority of licorice over existing chemical drugs such as omeprazole. $(P<0.01)$ Of course, the synergistic effect of tragacanth and licorice, using different doses, should be investigated in another study.

In a study by Kjayyal et al. (2001), they studied the effects of aqueous extracts of Lemongrass, Siberian, Chamomile, Cumin, Mint, Licorice, Angelica and Marianlu thistle on the anti-ulcer activity of these extracts in combination in the gastrointestinal tract. The results of antitumor activity of the extracts were confirmed histologically and studies showed that the use of several extracts together based on the dose can reduce the amount of acid and increase mucin secretion, increase the release of prostaglandin E2 and decrease leukotrienes. The effect on pepsin content was relatively variable and did not appear to be related to antitumor activity. The most effective effect of aqueous extract of Glycyrrhiza glabra and asparagus at a dose of $10 \mathrm{mg} / \mathrm{kg}$ of rat body compared to 100 $\mathrm{mg} / \mathrm{kg}$ of cimetidine was shown on the rat gastric ulcer, which differs from the dose of aqueous extract in this study. In this study, a combined aqueous extract of Glycyrrhiza glabra and tragacanth at a dose of 200 $\mathrm{mg} / \mathrm{kg}$ was used in comparison with omeprazole. The difference between the dose in this study and the above study shows that based on the type of active ingredients in each plant, even with the same efficiency, the dose is different and the synergistic effect of plant extracts is very different based on their dose and even possible side effects. Extracts can be combined with a dose-based manner that requires extensive laboratory research (10).

In the study of Nafeeza et al. (2002), aspirin was very effective in causing ulcers only in the gastric lining and had no effect on intestinal tissue, but However, in this study, according to the results, tissue changes occurred in the intestinal tissue, which was less severe than in the stomach and is quite evident in the pathology images taken. The rate of inflammation has decreased, but the aqueous extract of Glycyrrhiza glabra continues to reduce the wound rate in the gut and increase the healing rate. $(P<0.01)$ The results of this study are different from the present study. (13) The etiology of gastric ulcer is still debated, but there is an imbalance between invasive factors and gastric mucosal defense mechanisms. Many people use NSAIDs daily to relieve digestive problems, especially stomach pain, and recent studies show that between taking this Pill and the occurrence of gastrointestinal lesions are associated with the release of free radicals (14).

Some herbs can have a positive effect on gastrointestinal function. According to some studies, herbs such as Glycyrrhiza glabra by inhibiting acid, increasing mucus production, stabilizing superficial epithelial cells and interfering with the production of prostaglandins in preventing ulcers and They are effective in wound healing (15).

Ramirez et al. (2004) also showed that the extract of some plants that have similar compounds in Glycyrrhiza glabra has an anti-ulcer effect on gastric ulcer, which the results of this study confirm this, of course, the effect of Glycyrrhiza glabra. In the intestine, it is only to the extent of reducing inflammation and complete recovery in intestinal lesions has not been achieved. (16) Glycyrrhiza glabra is a genus of herbaceous plants and due to the active compounds present in the rhizome of this plant, it has known anti-ulcer properties and often has compounds of flavonoids, isoflavones, hydroxycoumarin, alkali derivatives, steroids and Fragile oils such as estragole and hexanoic acid have many fatty properties, including antioxidant properties. In the studies of Nolan et al. (2005) the protective effect of flavonoids on the improvement of wound ulcers in the gastric lining has been shown to be pathologically consistent with the present study (17).

A study by Jia, T et al. (2017) found that another flavonoid called licoriceidin is present in Glycyrrhiza glabra root, which has anti-inflammatory effects on chondrocyte osteoarthritis. It is oxidized to prostaglandins and nitric oxide, followed by the Nrf2 pathway, a lotion-based protein and transcription factor encoded in humans by the NFE2L2 gene, by inhibiting oxidative compounds from free electron production and increasing extracellular calcium, thereby causing inflammation. Prevent. Liquoridine is an antispasmodic and anti-inflammatory, antioxidant found in Glycyrrhiza glabra root (20).

The results of this study had an inhibitory effect on chondrocyte inflammation and in this study the use of aqueous extract of Glycyrrhiza glabra in the stomach reduced lymphocyte diffusion and bleeding compared to the control group which indicates the positive effect of aqueous extract of Glycyrrhiza glabra on wound healing. The use of aqueous extract of Glycyrrhiza 
glabra and tragacanth completely erases the pathological changes and shows a completely normal histopathological pattern, which clearly shows the synergistic effect of aqueous extract of Glycyrrhiza glabra and tragacanth compared to the results of Jia T research (20).

\section{Conclusion}

Although the anti-ulcer effect of aqueous extract of Glycyrrhiza glabra can be attributed to the chemical compounds in the plant extract, its exact mechanism remains unknown due to the few studies available. Increasing free radicals as a result of aspirin consumption and the effect of vitamin $C$ in reducing them and the protective effect of flavonoids, sterol and isoflavones by strengthening the mucosal barrier are some of the things that protect the plant against aspirin ulcers in the stomach and reduce aspirin-induced inflammation in the intestine. The cheapness, nativeness and availability of these plants are important factors that lead researchers to use medicinal plants in the treatment of infections. The results of the present study show that the aqueous extract of Glycyrrhiza glabra is effectiveness of healing of gastric ulcer and the relative effect on the healing of intestinal ulcers. The synergy of tragacanth and Glycyrrhiza glabra completely eliminates the pathological changes and creates a normal histopathological pattern in the stomach and a relatively normal one in the intestine. In future studies, the possible pathways of antiinflammatory action should be identified by accurately identifying the active ingredient of Glycyrrhiza glabra and tragacanth and determining the exact mechanisms that improve their effect in the treatment of gastrointestinal infections. According to the results of this study and the mentioned properties of Glycyrrhiza glabra and the absence of side effects on the body, the use of Glycyrrhiza glabra and tragacanth is recommended based on the instructions of experts.

\section{Acknowledgment}

This research is one of the research projects of the Sampad High School in Tehran, which has been carried out in the laboratory of the Islamic Azad University, North Tehran Branch and the boarding house of Baqiyatallah University. The authors thank Dr. Barkhordari and Dr. Amini.

\section{Funding}

Funding for this research has been entirely the responsibility of the authors.

\section{Conflict of Interest}

Authors declared no conflict of interests. 


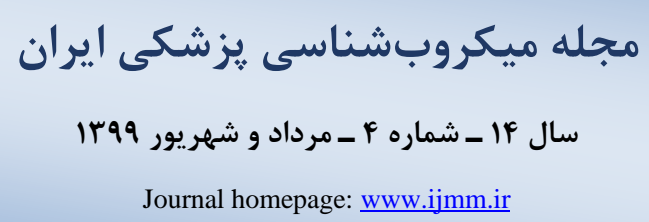

Journal homepage: www.ijmm.ir

\section{بررسى اثر همافزايى شيرينبيان و كتيرا بربهبود زخم دستكاه كوارشى موش صحرايى}

\section{محدثه لارى يور اثق، الهام اخوان سيههى ‘ آنيتاسادات طباطبايى علوى}

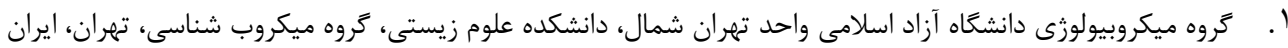

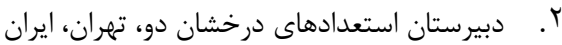

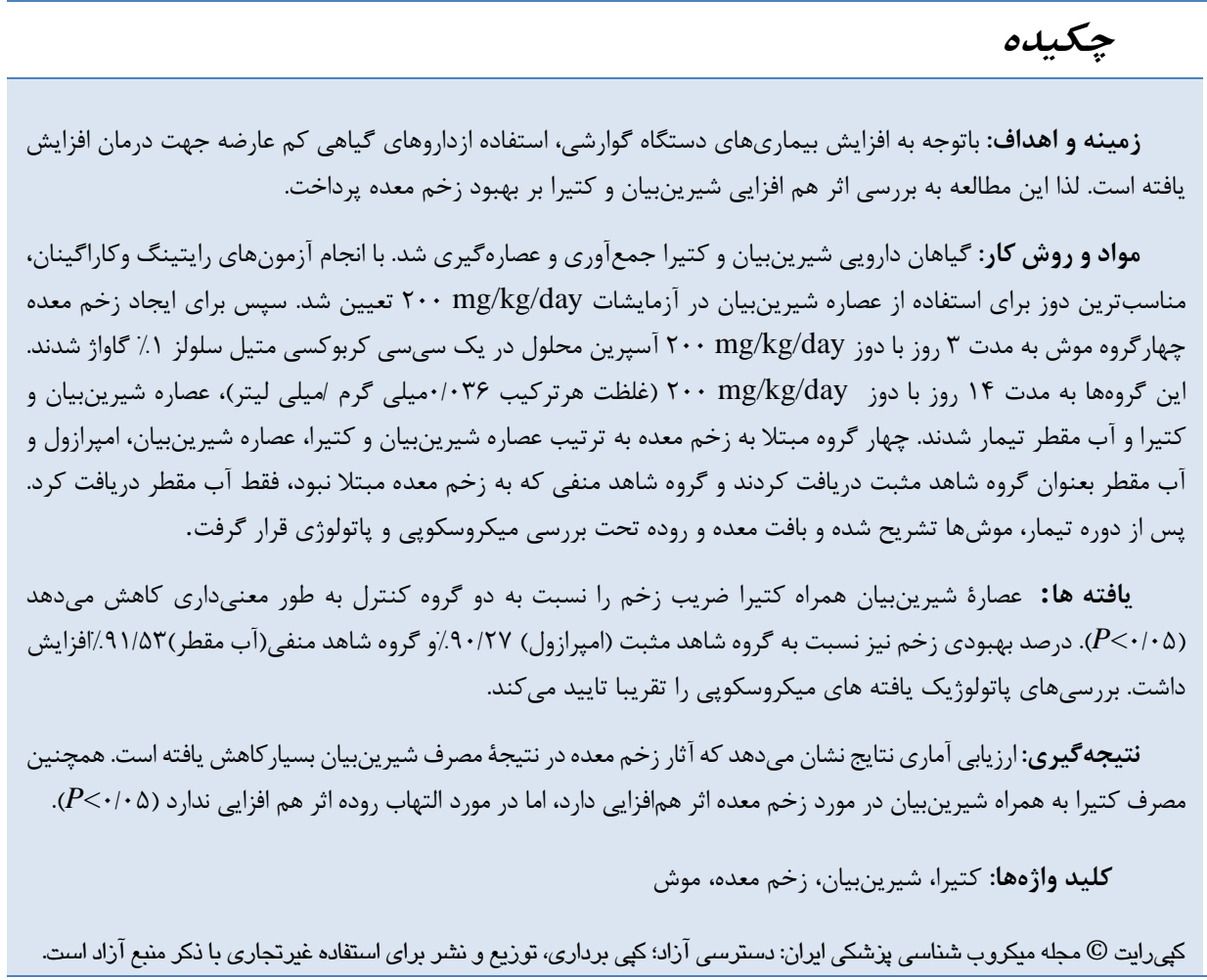

اطلاعات مقاله

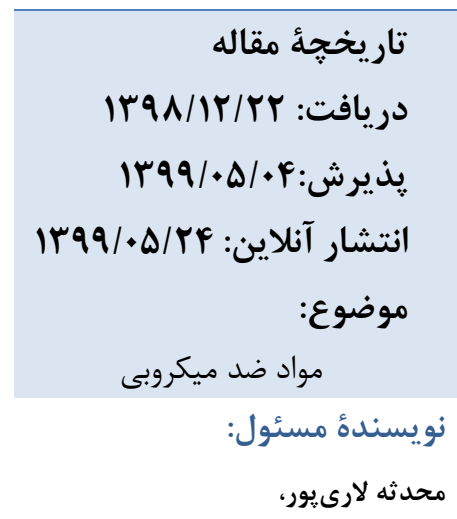

استاديار تروه ميكروبيولوزى دارئن دانشكاه آزاد

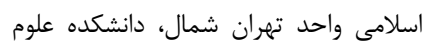
زيستى، كروه ميكروب شناسى، تهران، ايران إندان ايميل:
قدرت شيرين كنندكى آنها . . 1-•ه برابر بيشتر از نيشكر است.

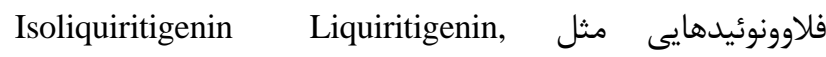
glabren, glabridin, و ايزوفلاوونوئيدهايى مثل Isolicoflavonol glabrol, 3-hydroxyglabro I glycyrrhisoflavoneريشه كياهى به وفور يافت مى شوند. تركيبات ديخرى از جمله

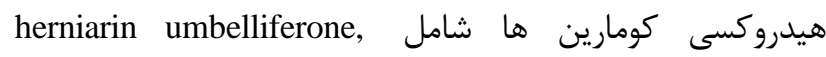
glycycoumarin, licopyranocumarin و مشتقات كومستان شامل sterols, واستروئيدها شامل glycyrol, isoglycyrol, liqcoumarin stigmasterol beta-sitosterol anethole, estragole, eugenol,hexanoic acid شيرينبيان يافت مىشوند. شيرينبيان از نظر طب قديمى ايران
شيرينبيان (Licorice) با نام علمى Glycyrrhiza glabra،

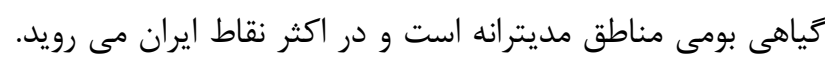

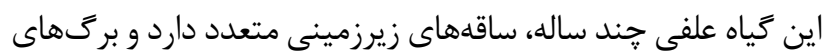

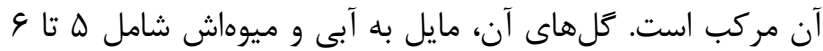
دانه تسبيحى شكل و قهوهاى است. اين كياه از خانواده يروانه آسا

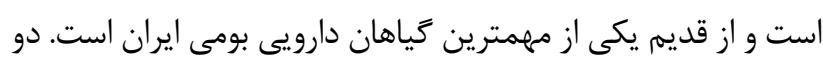

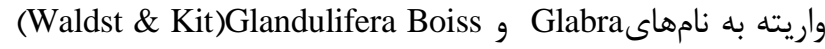
از آن شناسايى شده است و مهمترين منطقه جمعآورى آن آن، استان

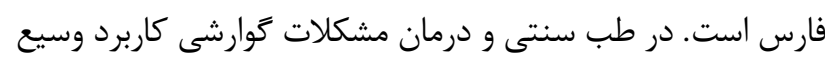

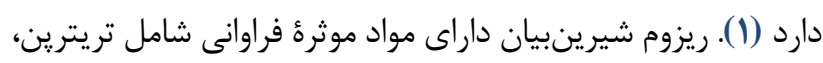
سايونين، كليسيريزين و r و أهيدروكسى كليسيريزين است كه 
بهره برداران بيست روز يس از برش به جمعآورى كتيرا مى يردازند

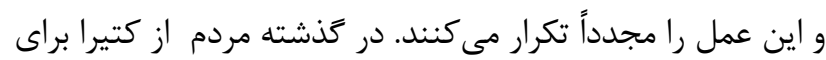

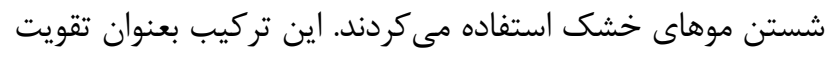

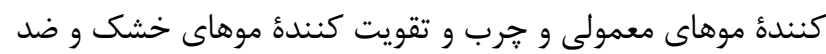

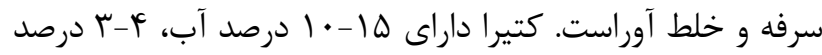

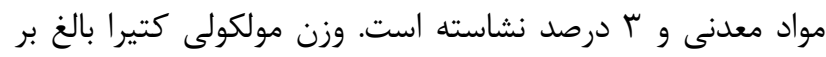

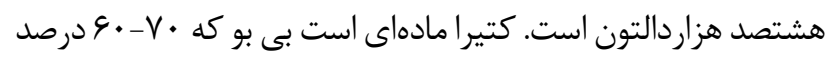

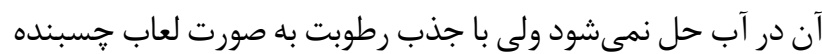

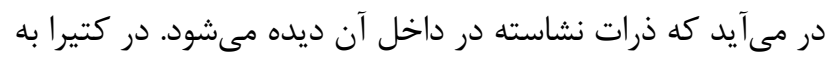

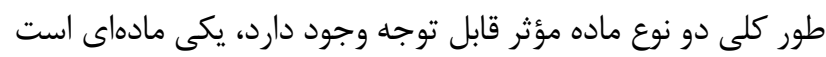

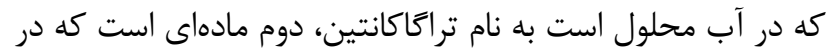

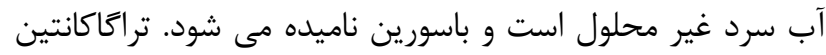

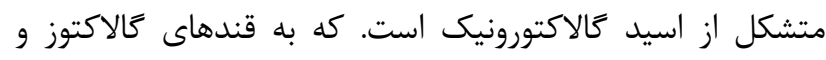

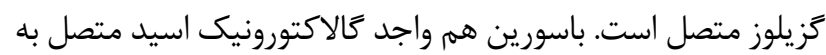
قندهاى كالاكتوز و گزيلوز مى باشد. اين مواد موثره مانع از طولانى

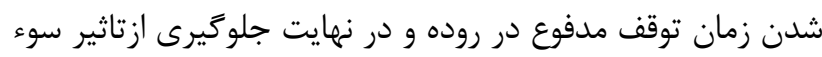

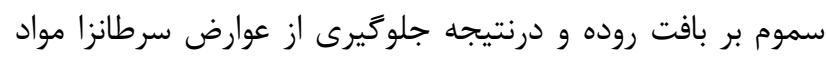

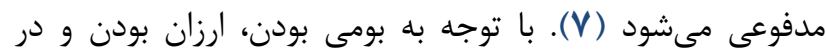

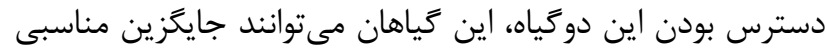

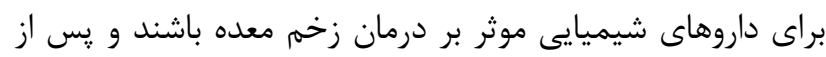
مصرف كمتر ين عوارض را داشته باشند.

زخمم معده از مهمترين بيمارىهايى است كه تعداد زيادى از

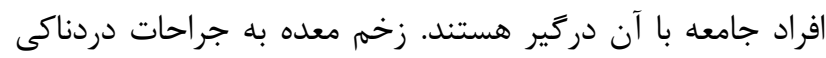

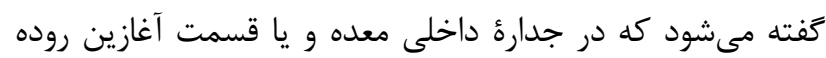

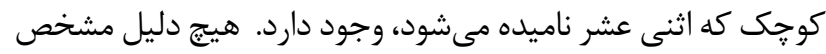
و واحدى براى بروز زخم معده يافت نشده است. با اين حال، امروزه

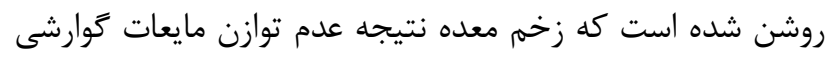

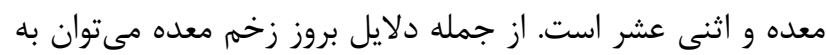
عفونت در اثر نوعى باكترى كه $\quad$ Helicobacter pylori ناميده

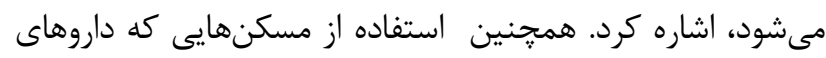

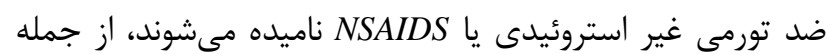
آسييرين، نايروكسن، ايبويروفن و داروهاى بسيار ديكر نيز مى تواند

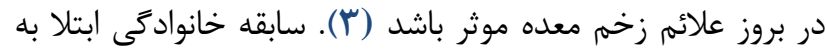

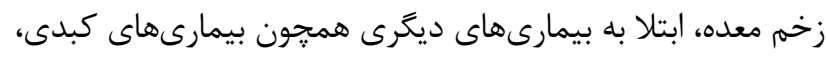

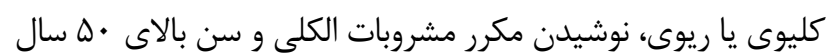

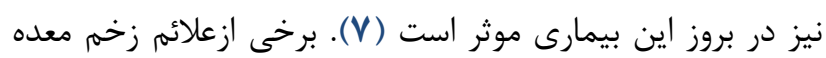

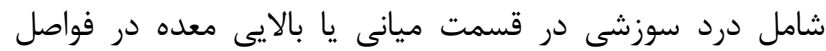

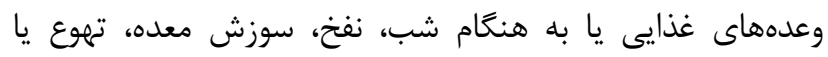

طبعى معتدل دارد. مهمترين خاصيت شيرينبيان كه به تازگى كشف شده است و در ارويا و امريكا استفاده مىشود، درمان زخما

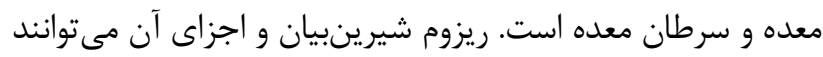

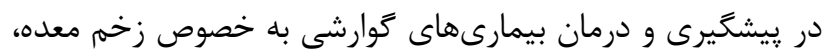
نفخ شكم، يبوست، ورم لوزه و هياتيت اثرات مفيدى داشته باشد.

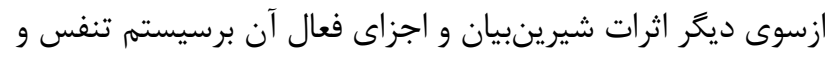
رفع سرفه، آسم و عفونت هاى قفسه سينه در مطالعات ديده شده آندان است (r). امروزه اثرات ضدسرطانى برخى از تركيبات شيرينبيان مشخص شده است. همجنين، اثرات مفيد شيرينبيان بر درمان

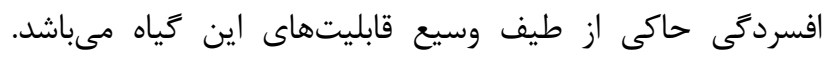

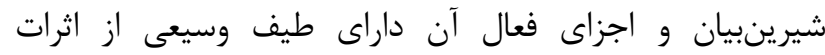

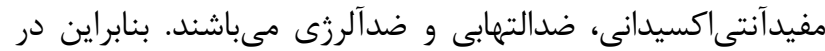

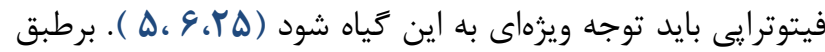

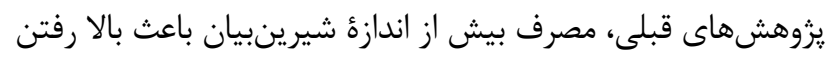

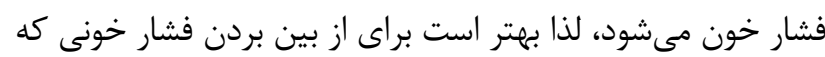

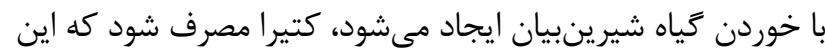

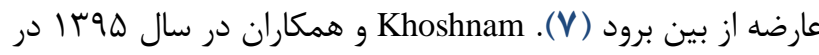
تحقيقى اثبات كردند كه همر اه شدن شيرينبيان (V) (90m/kg) همراه

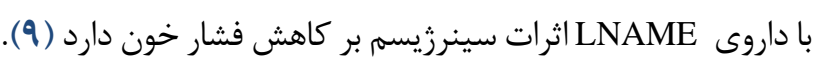
كتيرا با نام علمى Astraglus gossypinus-، صمغ و شيرة كياهى به نام كَن است كه كَونهاى مختلفى دارد. كَون به صورت

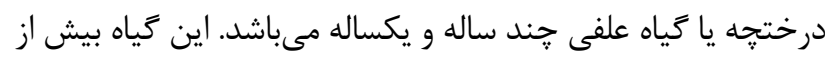

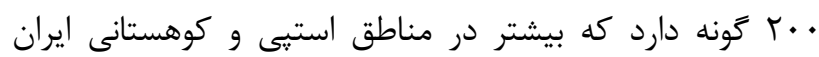

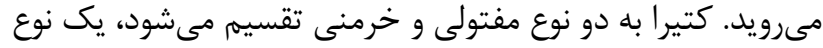

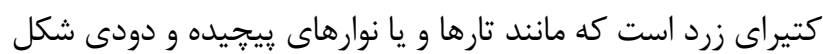

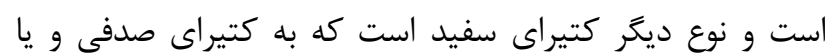

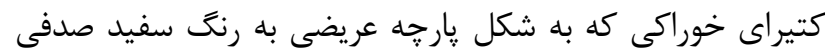

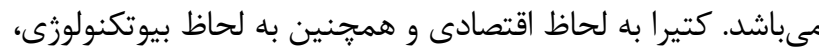

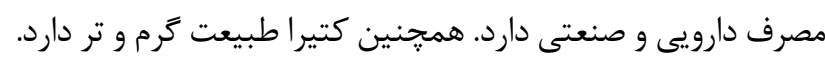
اين صمغ خودبخود و يا معمولاً بر اثر شكافى كه در ساقؤ كون ايجاد مىشود، جارى مى

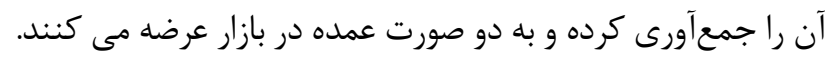

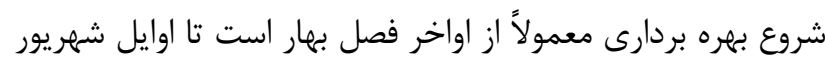
ماه ادامه دارد. بهره برداران ابتدا اطراف ساقه كون را خالى ميى كنند

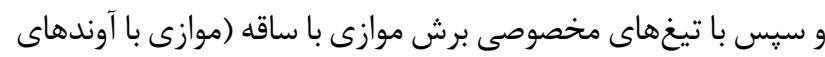

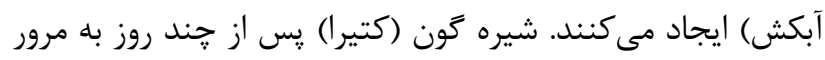

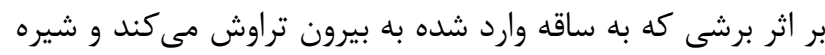

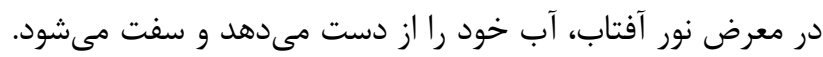


ميلى ليتر بر كيلوكرم وزن بدن با غلظت و ا•درصد تزريق شد و

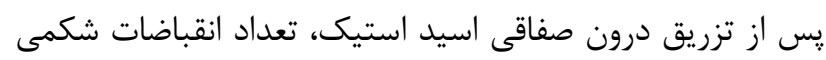

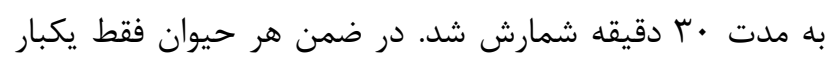

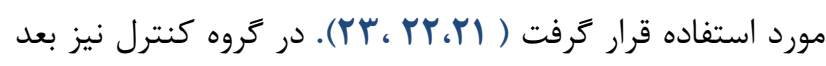
از تزريق درون صفاقى سرم فيزيولوزى، آزمون ريتينَ انجام شد.

\section{آزمون كاراتينان}

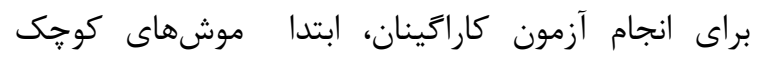

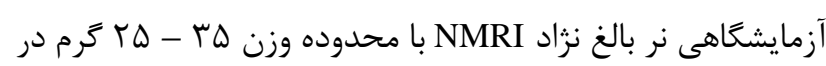

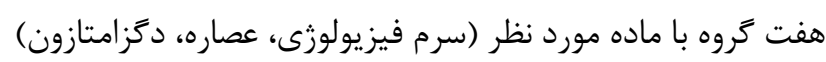

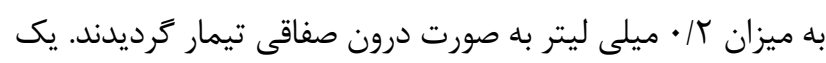

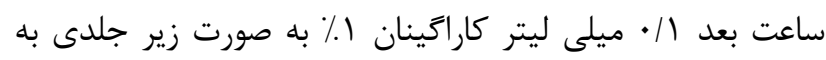

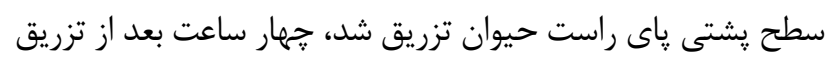

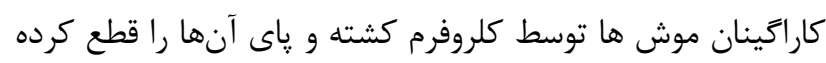

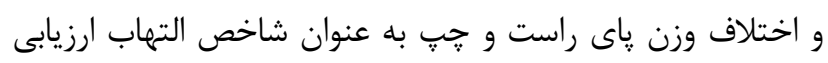

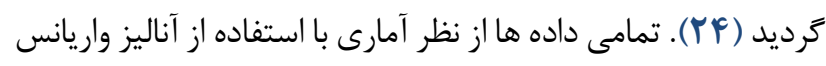

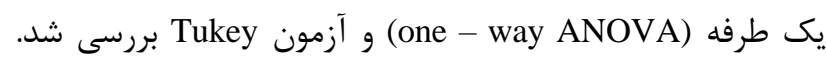

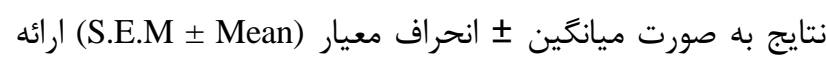

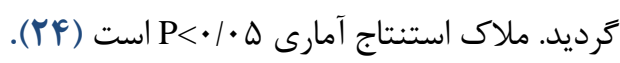

\section{تهيه كياه دارويى}

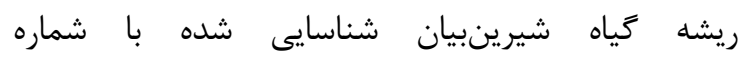

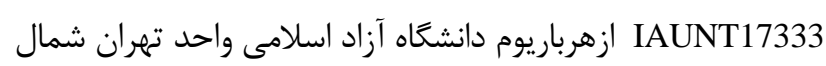

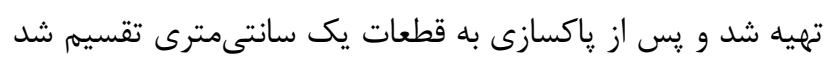

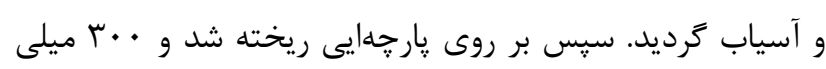

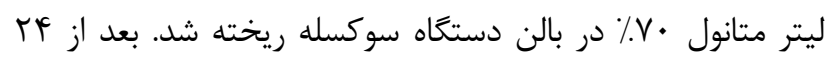

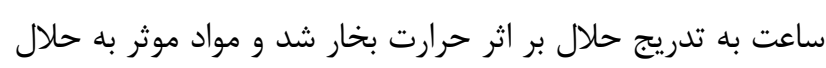

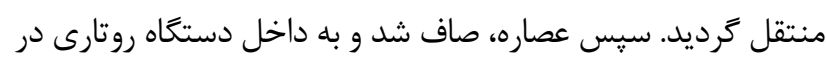

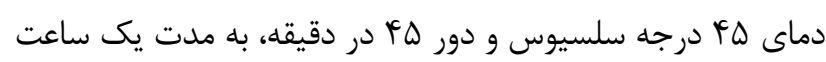

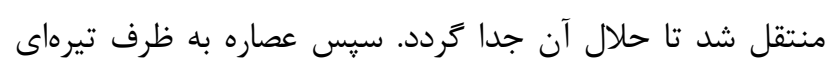

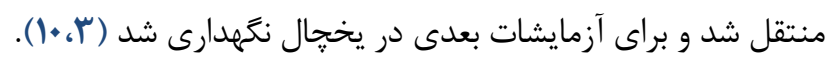
كتيراى خوراكى با شماره IAUNT17334 از هرباريوم

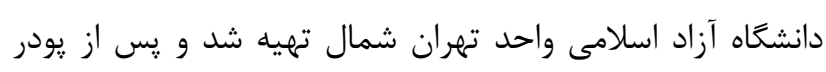

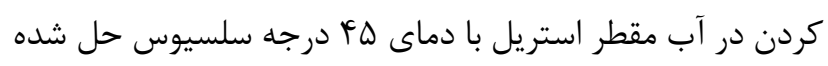

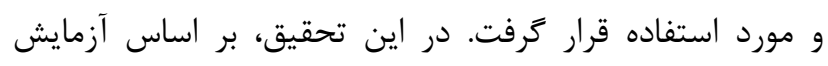

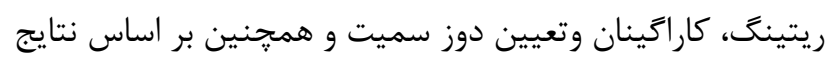

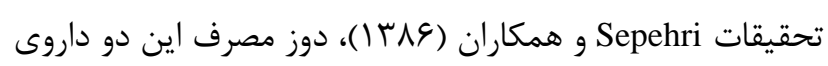

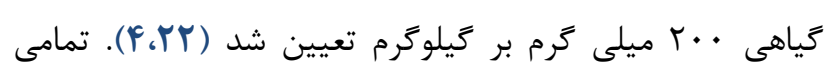

استفراغ، مدفوع سياه يا تيره (به دليل خونريزى)، بالا آوردن خون،

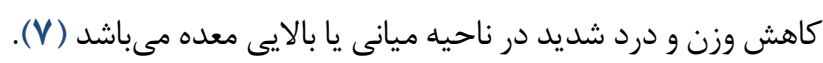

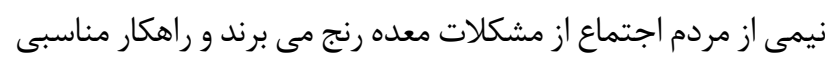

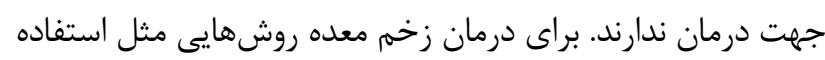

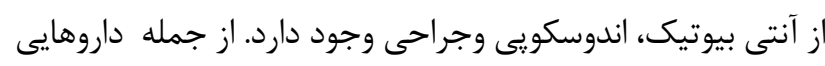
مثل Prilosec, Prevacid, Aciphex, Protonix, Zegerid در درمان زخم معده استفاده مىشود كه هم عوارض زيادى دارد و هم كران

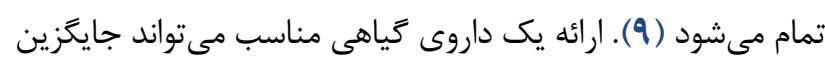

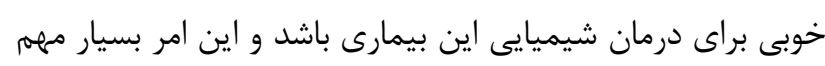

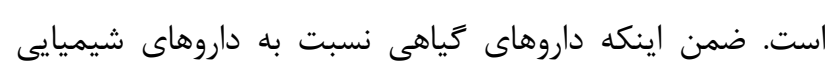

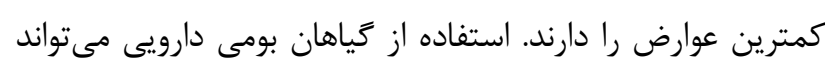

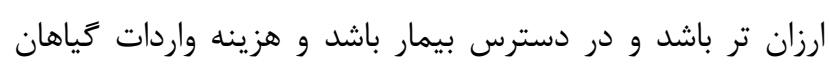

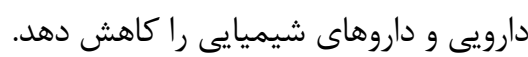

\section{روش یخوهش}

اين مطالعه مربوط به يك يزوهش تجربى دو نفر از دانش

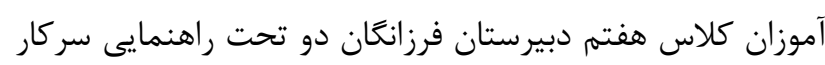

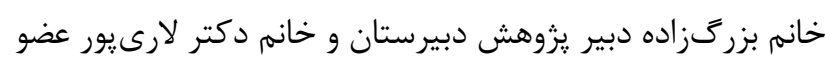

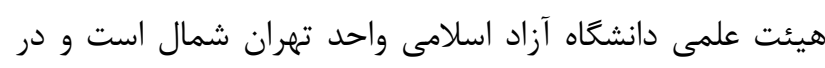

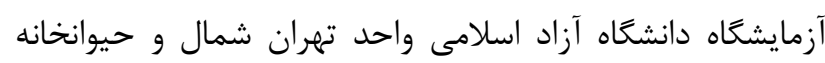
بيمارستان بقيه الله تهران انجام شده است.

\section{ارزيابى دوزهاى موثر شيرينبيان}

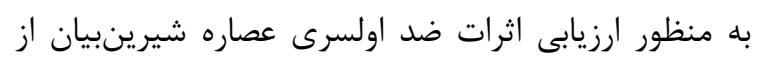

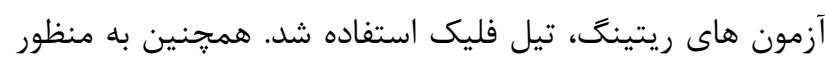

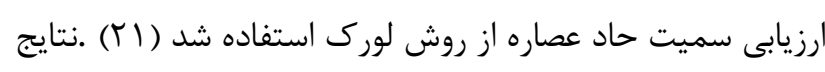

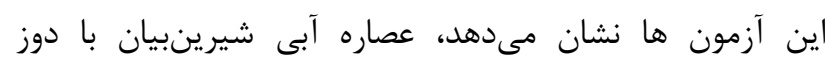

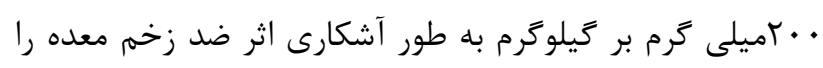

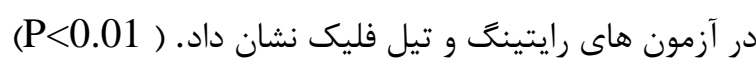

\section{آزمون ريتينَ}

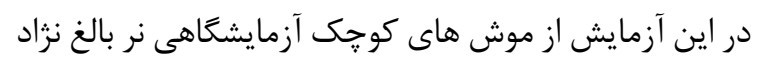

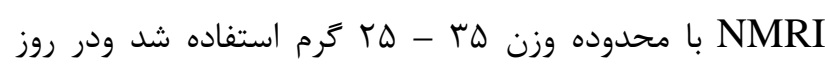

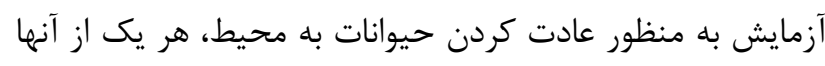

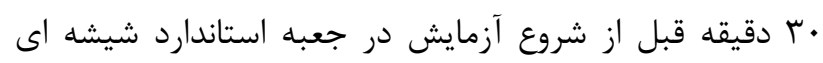

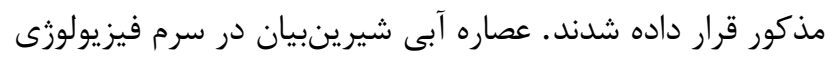

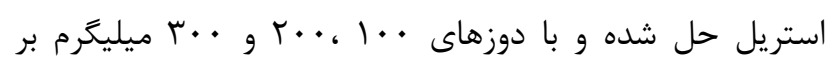

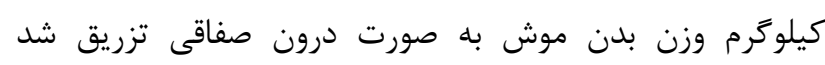

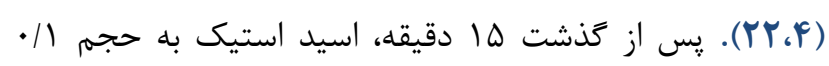


F- كروه جهارم يا شاهد مثبت موشهاى مبتلا به زخم معده كه با آب

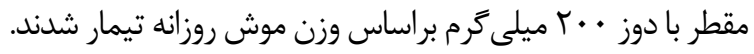

ه-كروه ينجم يا شاهد منفى كه زخم معده نداشتند و با آب مقطر

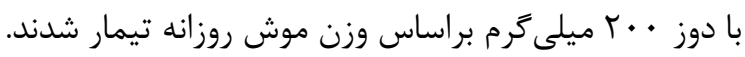

يك موش هم براى تعيين ايجاد زخم معده بعد از دوره

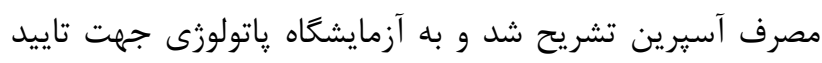

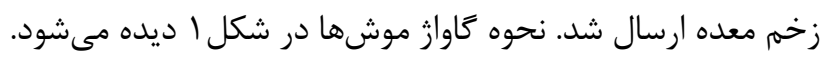

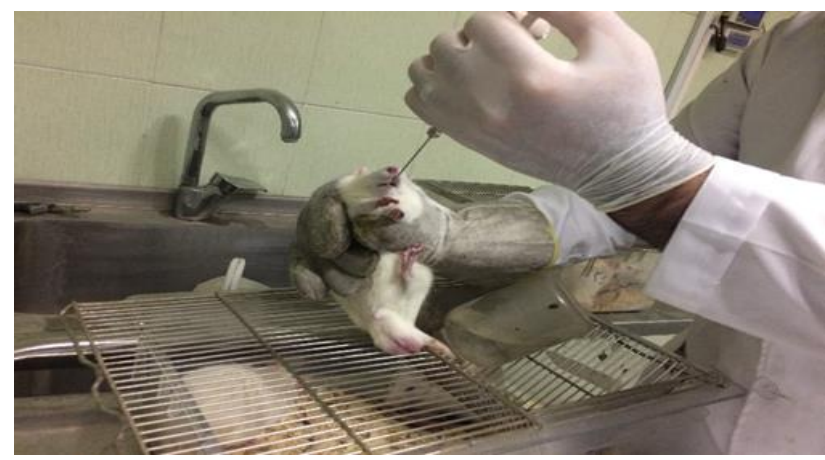

شكل ا. نحوه كَاواز عصاره ها در موش

سه ساعت يس از آخرين دوز تزريق، حيوانات همه كروهها

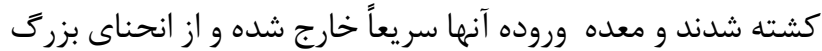
برش داده شد و سيس توسط ياتولوزيست نوع زخم و خونريزى و

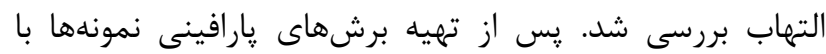
استريوميكروسكوٍ (Lica Zoom 2000) مشاهده شدند. ضايعات Wild معده و روده، بطور جداخانه بررسى و با كمك گراتيكول

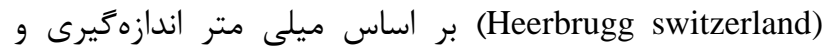

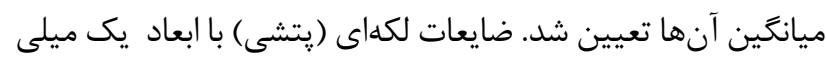

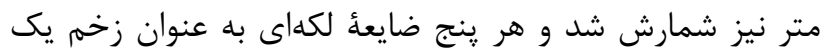
ميلىمترى در نظركرفته شد.

$f \mathrm{~mm}=\omega-9$

$r m m=r-\varphi$

$r m m=1-r$

ضايعات بزركتر ازع ميلى متر برابر با ه در نظر كرفته شد.

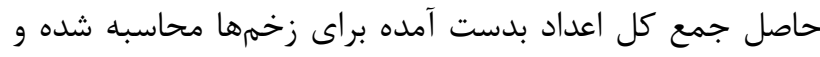

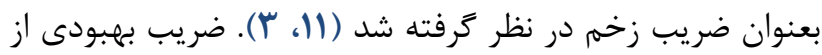

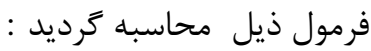

ضريب بهبودى =.1 × ضريب كنترل زخم اضريب زخم تيمار - ضريب كنترل زخم يس از محاسبات ميكروسكويى، معدهها ورودهها در بافر فرمالين

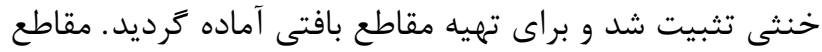

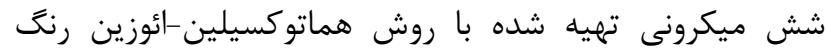
آميزى شده و براى تفسير به صورت كور و بدون اطلاع از كروههاى
محلولها جهت استفادهاى بعدى، در دماى f أ درجه سلسيوس

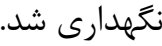

\section{(LD50)}

اين تست بر اساس متد (Dietrich Lorke,1983) انجام شد

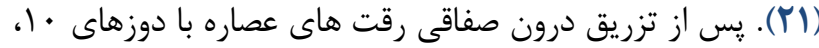

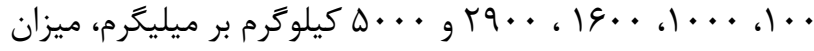

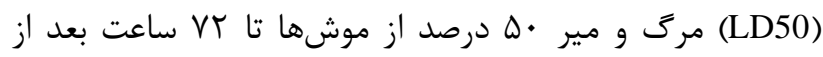
تزريق بررسى شد.

\section{بررسى اثرات عصاره آبى شيرينبيان و كتيرا در شرايط}

\section{in Vivo}

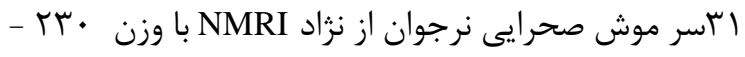

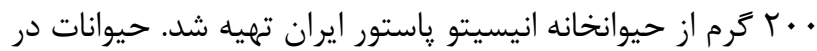
قفسهاى داراى كف تورى بلند به منظور ممانعت از مدفوع خوارى

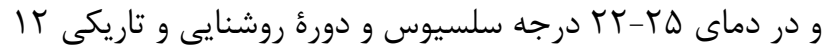

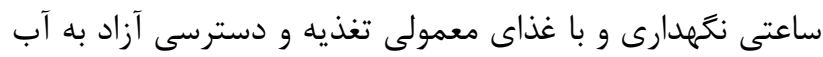

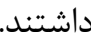

به منظور تخليه معده، همه حيوانات بغير از شاهد منفى به

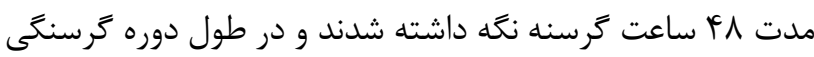

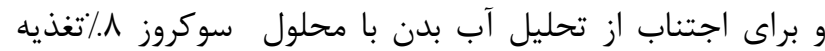
شدند. سيس لاكروه موش به مدت ب روز با آسيرين با دوز

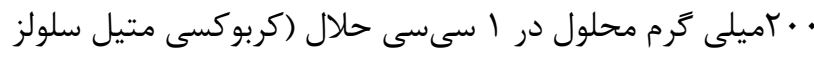

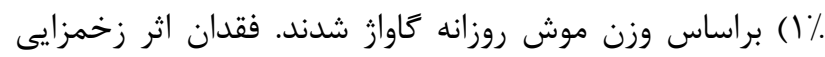

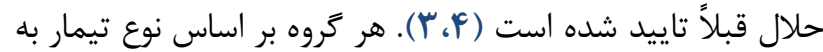
مدت flf روز، عصاره شيرينبيان و كتيرا (غلظت هرتركيب

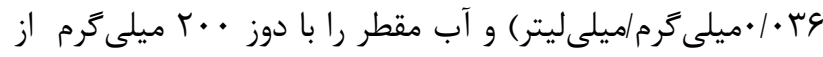

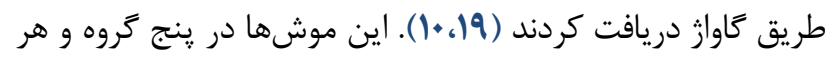
كروه واجدو سرموش طبقه بندى شدند و به مدت دو دو هفته تيمار

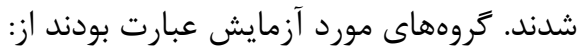

1- تروه اول موشهاى مبتلا به زخم معده كه با عصارة شيرينبيان و

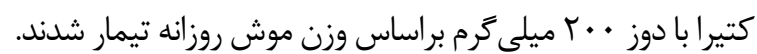

r- گروه دوم موشهاى مبتلا به زخم معده كه با عصاره شيرينبيان با دوز · · ميلى كرم براساس وزن موش روزانه تيمار شدند. r- گَروه سوم موشهاى مبتلا به زخم معده كه با اميرازول با دوز • . . ميلى كرم براساس وزن موش روزانه تيمار شدند. 


\section{يافتهها \\ نتايج سميت حاد}

با توجه به نتايج جدول اتزريق عصاره كياه شيرينبيان در بازه

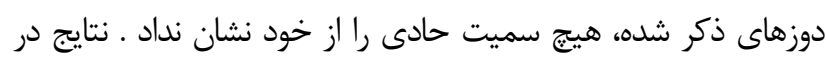
جدول انشان داده شده است.

آزمايش در اختيار ياتولوزيست قرار داده شد. تصاوير ميكروسكويى با دوربين و ميكروسكوب CH30 Olympus كرفته شد و تصاوير ماكروسكويى مستقيما با دوربين ديجيتال ترفته شد.

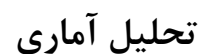

نتايج با آزمون Anovoa تيك طاري طرفه وبا استفاده از نرم افزار

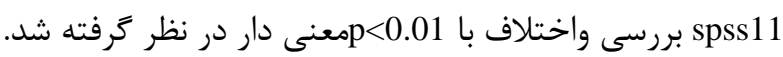

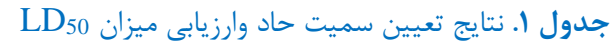

\begin{tabular}{|c|c|c|c|}
\hline \multicolumn{2}{|c|}{ دومين مرحله از تست سميت حاد } & \multicolumn{2}{|c|}{ اولين مرحله از تست سميت حاد } \\
\hline ماده ودوز مصرفى & تعداد حيوانات / مرك ومير & ماده ودوز مصرفى & تعداد حيوانات / مرگ ومير \\
\hline AEGg $1600 \mathrm{mg} / \mathrm{kg}$ & $\cdot / 11$ & AEGg $10 \mathrm{mg} / \mathrm{kg}$ & $\cdot / r$ \\
\hline AEGg 2900 mg/kg &.$/ 11$ & AEGg 100 mg/kg & $\cdot / \mu$ \\
\hline AEGg5000 mg/kg & .111 & AEGg $1000 \mathrm{mg} / \mathrm{kg}$ & $\cdot / \mu$ \\
\hline
\end{tabular}

\section{نتايج آزمون رايتينَ}

نمودار ا انشان داده شده است. جنانجه در نمودار امشاهده مىشود، افزودن

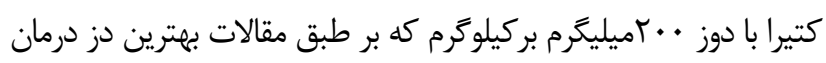
زخم معده محسوب مىشود، كاهش معنى دارى در مقايسه با كروه كنترل

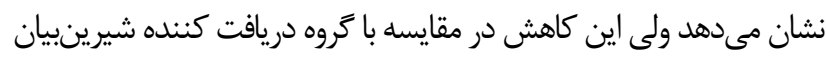

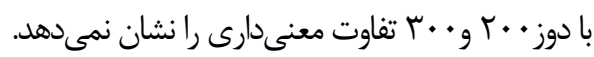

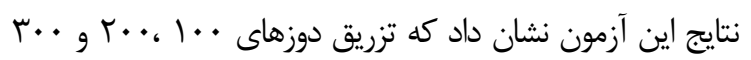

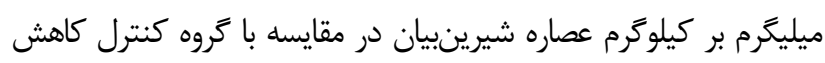

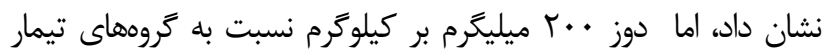

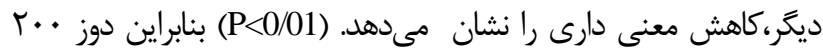

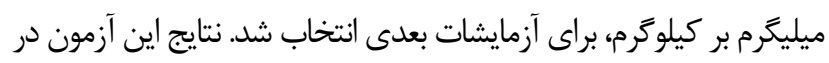

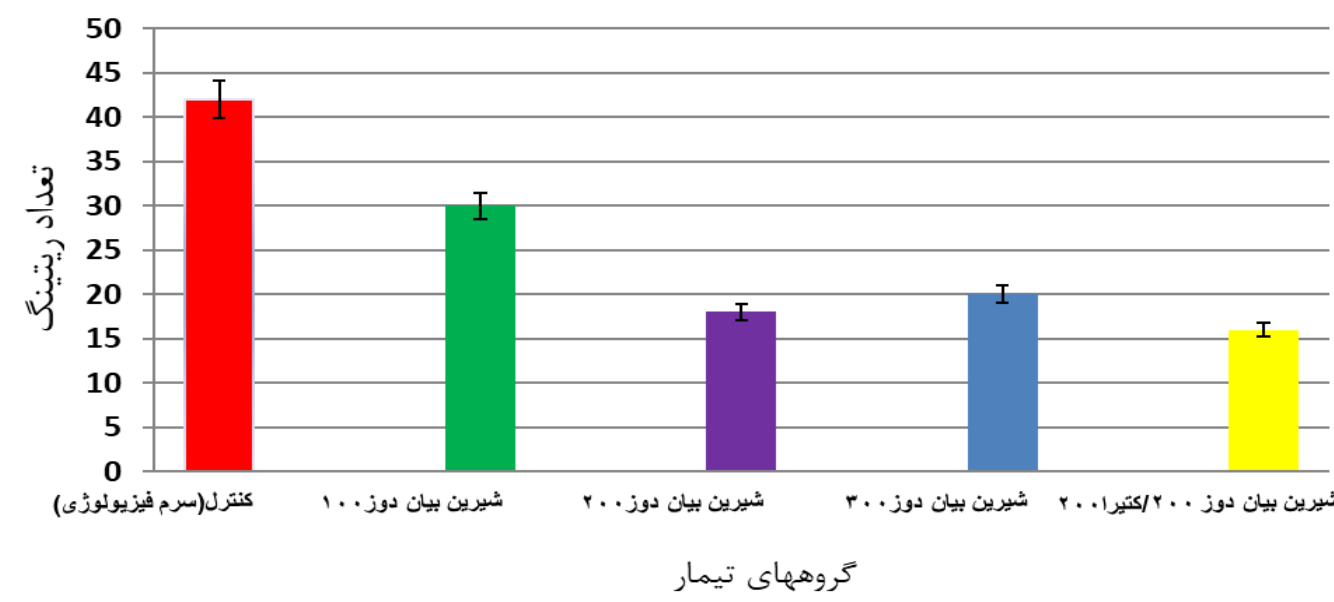

نممودار ا. مقايسه ميانگين تعداد ريتينگ موش صحرايى با غلظت هاى مختلف عصاره آبى شيرينبيان در آزمون اسيداستيك ( 0.01$)$

\section{نتايج آزمون كاراكينان}

دَزامتازون در دوز • ا ميلى گرم بر كيلوگرم وزن بدن به صورت

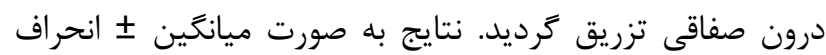

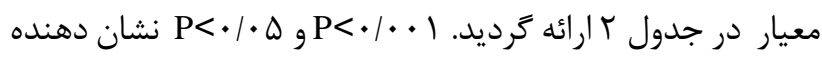
اختلاف با گروه كنترل مىباشد.
در اين آزمون اثر ضد التهابى عصاره آبى گياه شيرينبيان بر

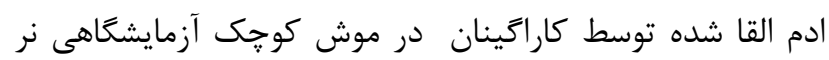

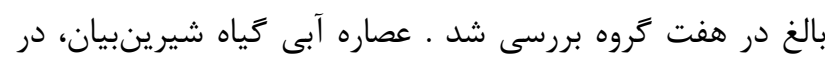

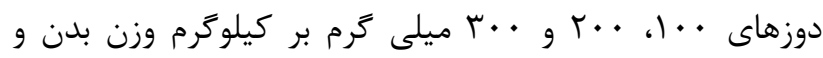


جدول r. بررسى اثر ضد التهابى گياه شيرينبيان بر ادم القا شده توسط كاراكينان در موش كوخى آزمايشكاهى نر بالغ

\begin{tabular}{|c|c|}
\hline اختلاف وزنى پِا راست و جٍِ & كروه \\
\hline$r \pm \Delta q / v q$ & 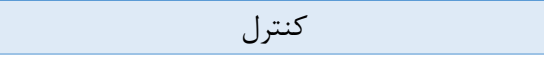 \\
\hline$r \pm \varphi \cdot / \Delta$. & 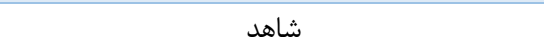 \\
\hline$\Delta \Lambda / r \pm I I / / Q *$ & عصاره ريشه(ميلى كرم بر كيلوكرم وزن بدن) .. \\
\hline $\mid \Lambda / T \pm \Delta \cdot / \Lambda r_{*} * * *$ & عصاره ريشه( • (Tميلى كرم بر كيلوكرم وزن بدن) \\
\hline$\cdot \pm r \Upsilon / \Lambda \Lambda * * * * *$ & عصاره ريشه( ·."اميلى كرم بر كيلوكرم وزن بدن) \\
\hline $1 \cdot / \Lambda \pm r \Gamma / V \Gamma$ 䊩 & د دَزامتازون \\
\hline
\end{tabular}

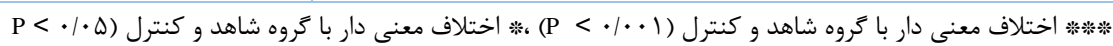

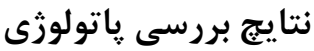

دريافت سه دوز متوالى آسيرين توانست در معده موشهاى تحت تيمار ضايعات مخاطى وزير مخاطى ايجاد كرده وسبب ايجاد

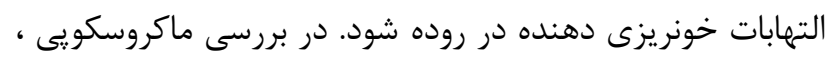

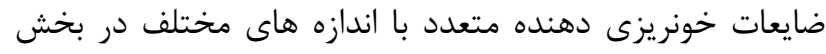

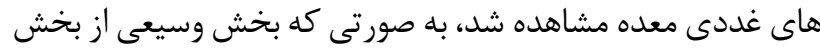

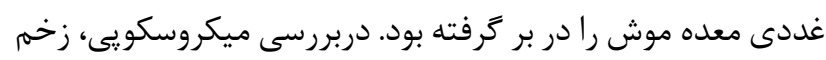

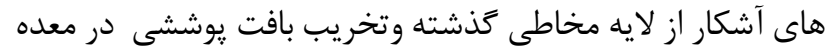

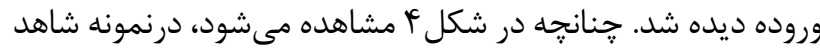

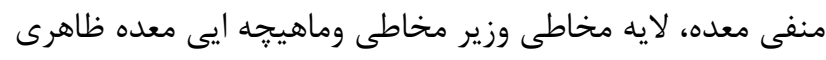

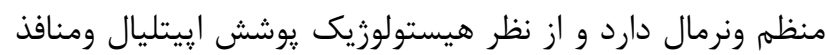

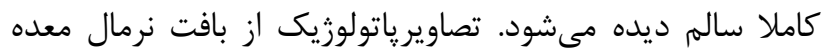
موش در شكل r نشان داده شده است.
نتايج تحقيق حاضر نشان داد كه تيمار عصاره كياه

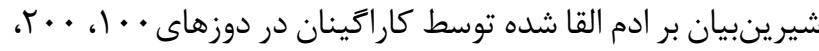

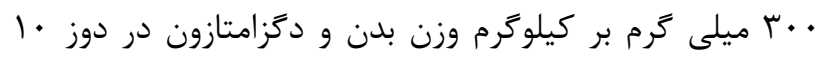

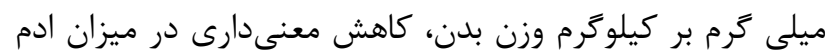

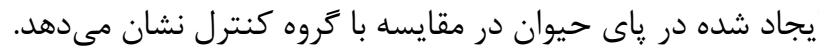

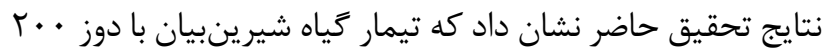

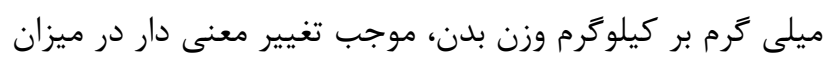

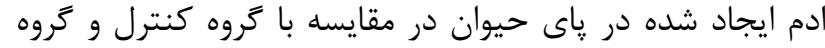

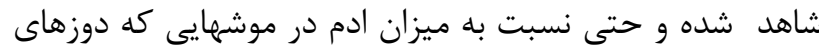

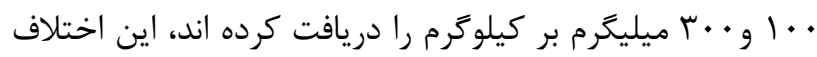
ادم معنى دار تر است ولذا بعنوان مناسب ترين دوز براى آزمايشات بعدى انتخاب مىشود، زيرا كاراگينان باعث ادم و در نتيجه افزايش

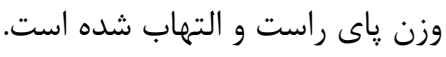
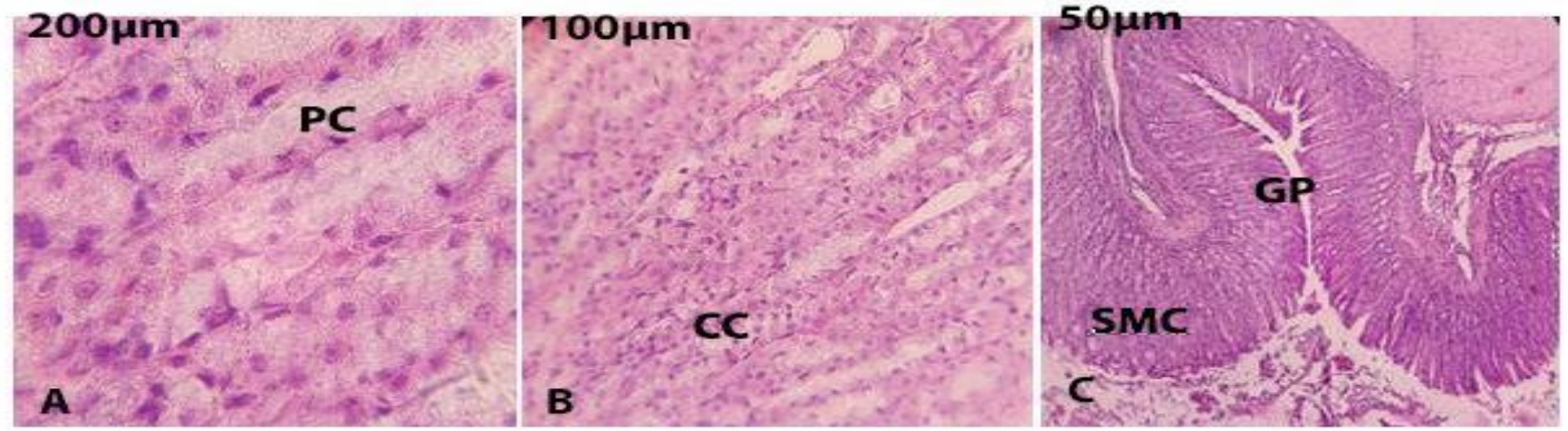

شكل r. مشاهده ظاهر منظم ونرمال وكاملا سالم يوشش ايِتليال معده موش بعنوان شاهد منفى PC: سلولهاى جدار معده، SMC: سلولهاى مخاطى سطحى،

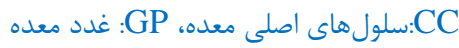

رفته و سلولهاى التهابى و لنفوسيتها قابل مشاهده مىباشند. ناحيه

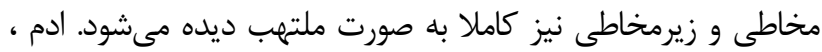
خونريزى و اتساع رگها در معده گَزارش گرديد.
درشكل ץ تغييرات هيستوياتولوزيك در بافت معده موش تيمار

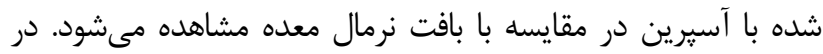
تصاوير مشخص است كه يوشش إيتليومى و غدد معدى كاملا از بين 

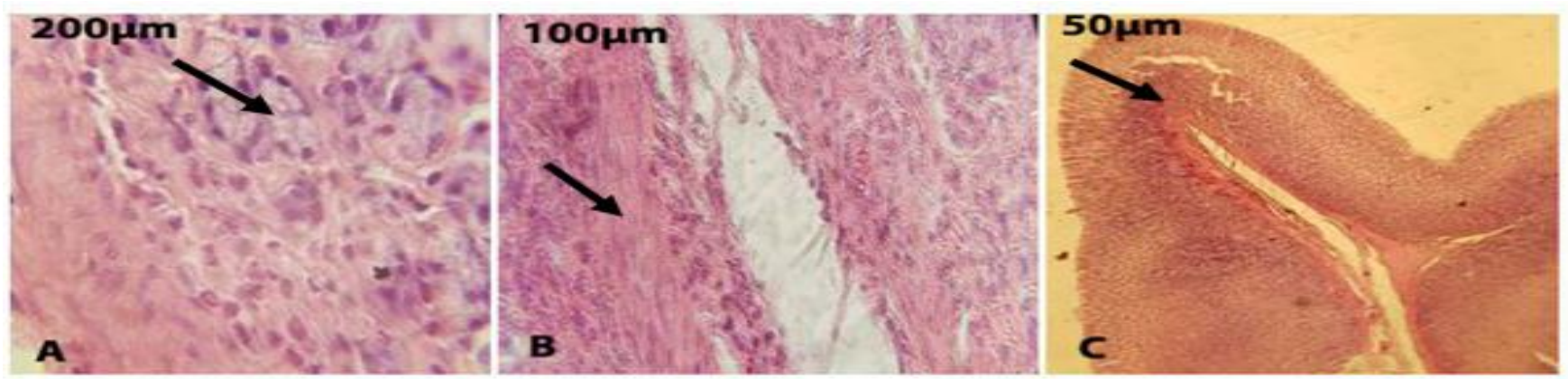

شكل r. مشاهده زخم معده موش در مقايسه با شكل r: إبيتليوم كاملا از بين رفته (B)واز بين رفتن غددمعدوى(GP) وإيبتليوم معده (PC) درشكل (A) وكاملا مشهود است.

رودهايى نرمال مشاهده مىشود. مقطع رنخ شده روده نرمال موش

$$
\text { در شكل f أ ديده مىشود. }
$$

در نمونه شاهد منفى و نرمال روده موش نماى يرزها در لايه

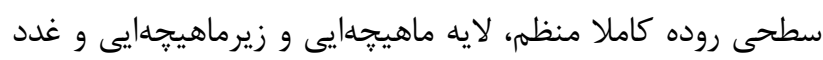
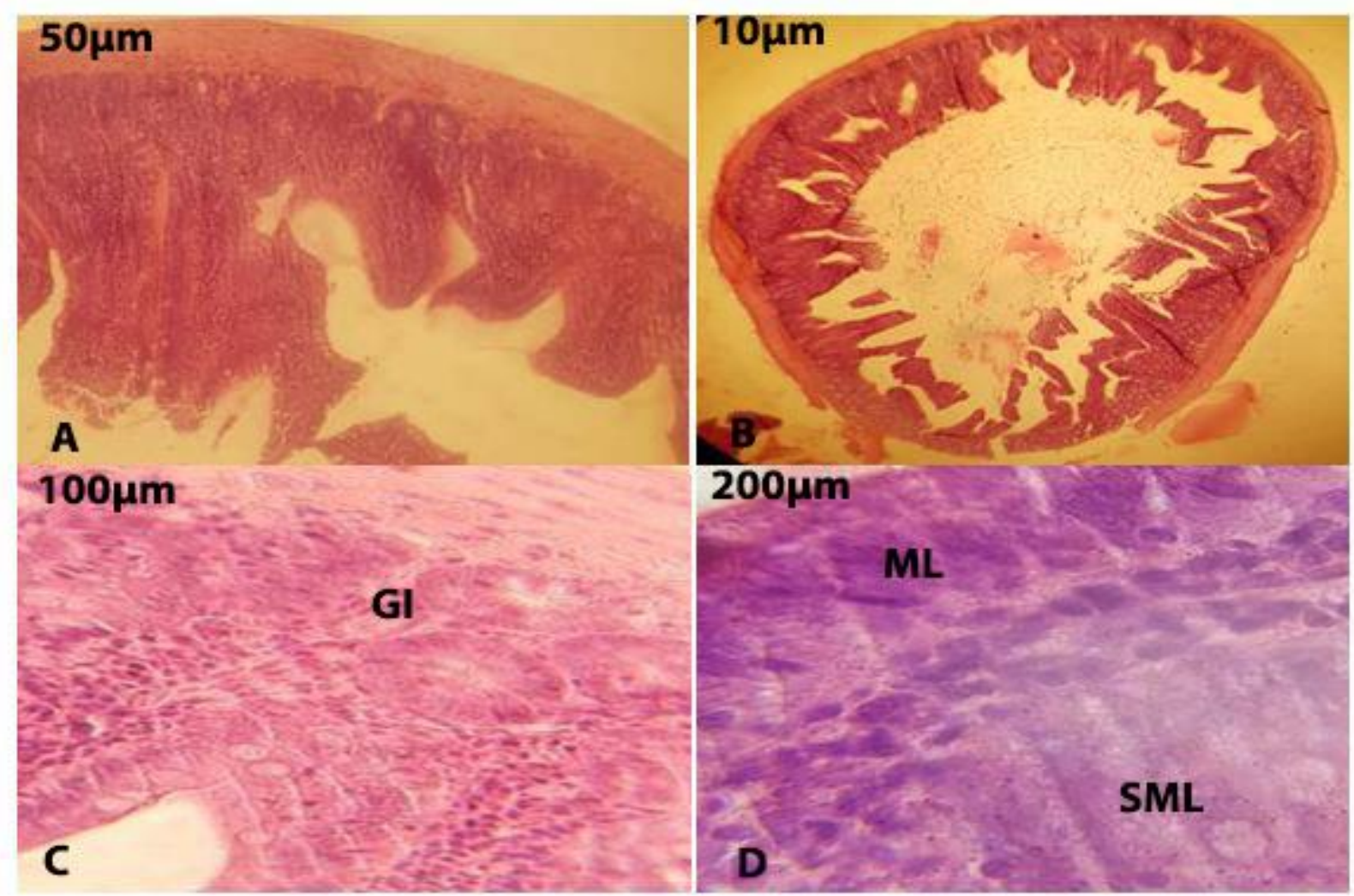

شكل F. مشاهده بافت نرمال روده موش بعنوان شاهد منفى،در شكل (C) غدد روده ايى (CI) كاملا مشخص است.در شكل (DI) لايه منظم ماهيجه ايى(ML) ولايه زير ماهيحه. ايى (SML) كاملا نرمال قابل مشاهده است.

مىشود. درشكل ه بافت ملتهب روده بعنوان شاهد مثبت ديده

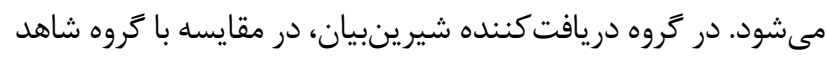

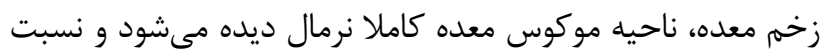

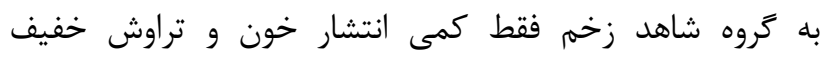

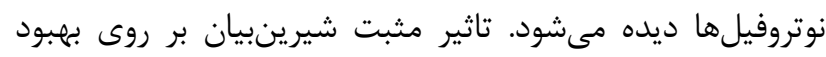

در نمونه هيستوياتولوزيك شاهد مثبت روده، التهابات و ارتشاح لنفوسيتها در مقطع رنت شده بافتى كاملا مشهود است.

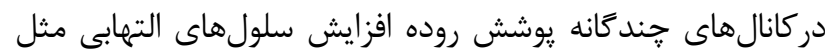

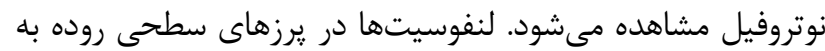

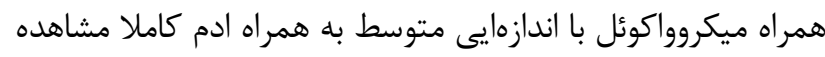


نوك ويلىها قابل مشاهده بود. در شكل 9 تاثير شيرينبيان بر روى

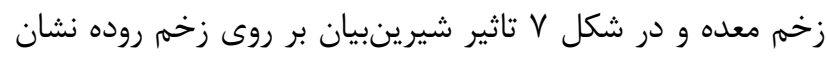
داده شده است.
كيفيت ضايعات קاتولوزيك هم مشاهده شد، اما نسبت به معده تاثير كمترى داشت و در ناحيه نوك يرزهاى روده، در قياس با نمونه شاهد

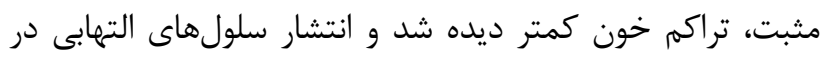
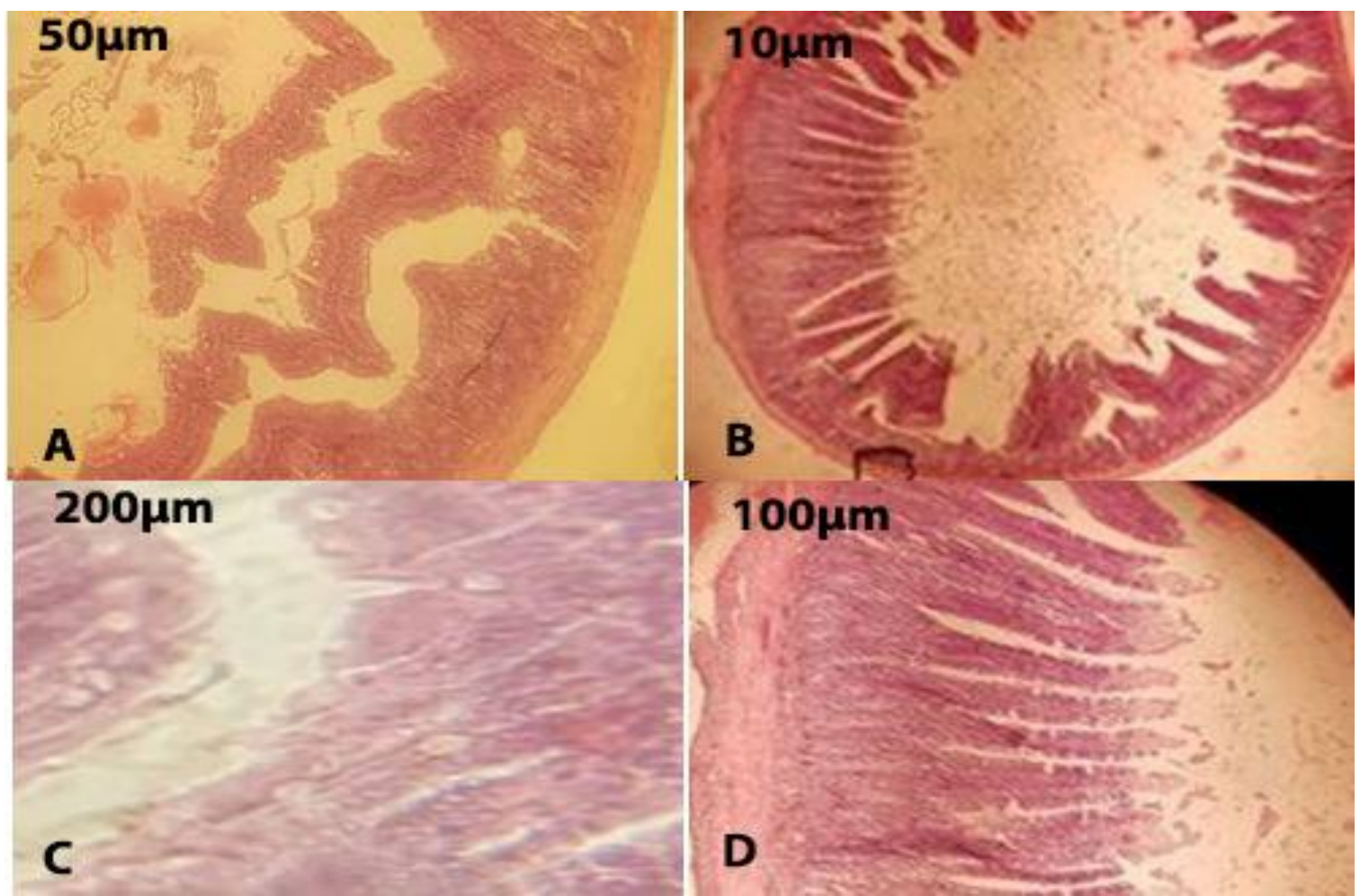

شكله. مشاهده التهابات روده موش يا شاهد مثبت روده تحت تاثير آسبرين (a) مشاهده حاشيه روده وافزايش التهاب،در شكل (D),(C) التهابات اختصاصى وترشح لوكوسيت ها در كانال هاى جندكانه ومشاهده ادم درسطح سلولهاى يوشش در محل فلش ها نشان داده شده است.
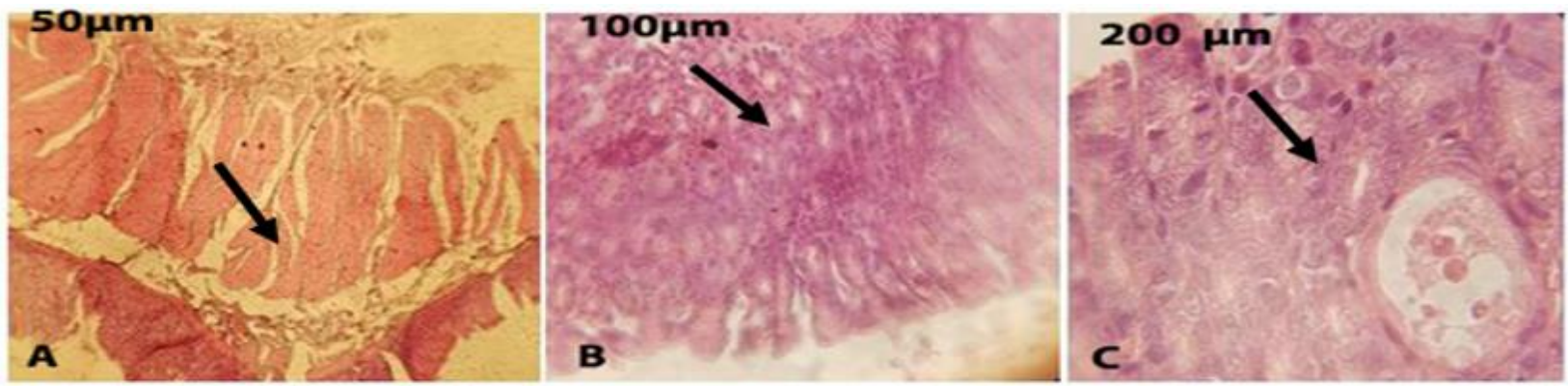

شكل 9. تاثير شيرينبيان بر روى زخم معده .درشكل (b)ميزان التهاب نسبت به نمونه شاهد زخم كاهش داشته و ساختار هيستولوزيك كاملا نرمال ديده مىشود اما در محل فلش تراوش خفيف سلولهاى نوتروفيل مشاهده مى شوده.

خفيف درنوك يرزهاى روده ديده شد كه نشانكر تاثير كمترشيرينبيان

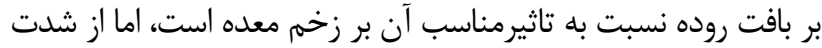
التهابات درمقايسه با كروه شاهد مثبت روده ، بسيار كاسته است.
همانطور كه در شكل V مشاهده مىشود وبر اساس بررسى داى ياتولوزيك، در كروه دريافت كننده شيرينبيان درروده، انتشارخفيف لنفوسيتها در ناحيه زير مخاطى ومخاطى به همراه نكروز والتهاب درياب دران 

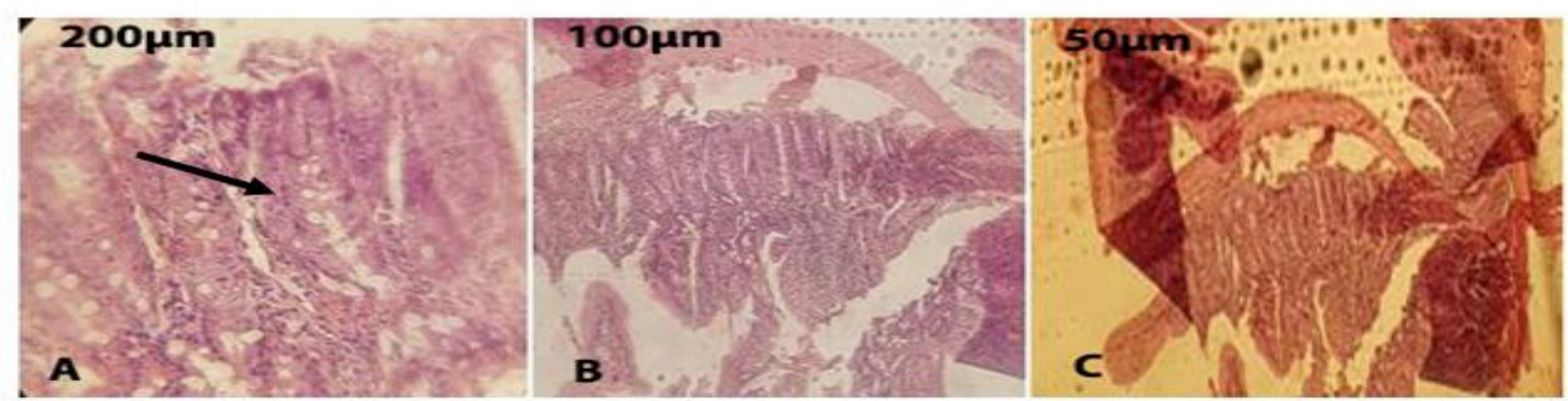

شكل Vا. تاثير شيرينبيان بر روى زخم روده نشان داده شده است.انشاز سلولهاى خونى در يرزهاى روده در محل فلش مشاهده مىشود وانتشار سلولهاى التهابى در نوك ميلى ها مشاهده مىشود.

نتايج بررسى ضريب زخم با نتايج پاتولوزيك همخوانى دارد.

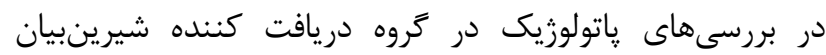
درمعده، موكوس معده كاملا نرمال مشاهده شد و انتشار خفيف درون

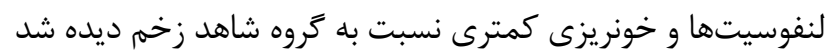
كه نشانكر تاثير مثبت شيرينبيان در بهبود زخم مى بعاشد. در كروه

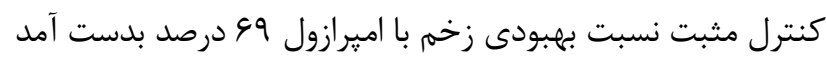

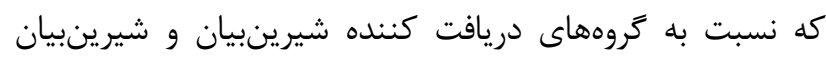

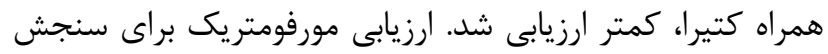

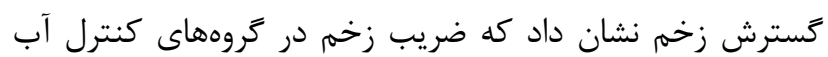

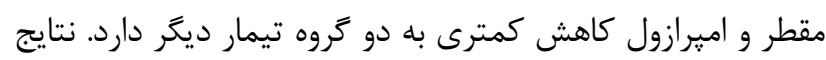

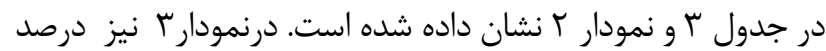
بهبودى زخم در گروههاى تيمار مقايسه شده است.
بررسىهاى ياتولوزيك ومحاسبه ضريب زخم نشان داد كه

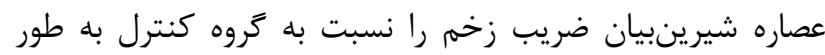

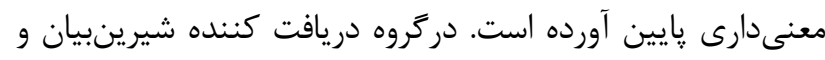

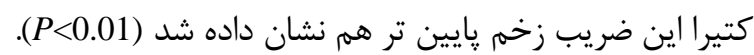
همينطور دركروه دريافت كننده عصاره شيرينبيان، درصد

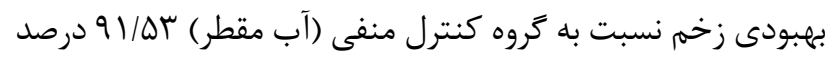

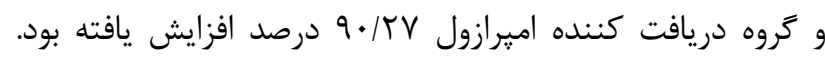
همجنين در كروه دريافت كننده تركيب عصاره شيرينبيان و كتيرا

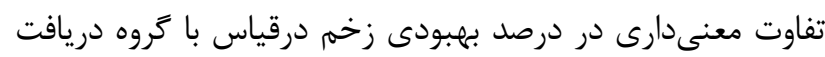

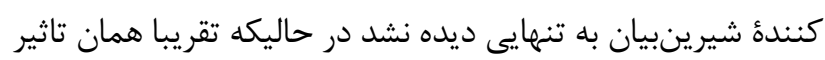
را در افزايش درصد بهبود زخم داشت (P>0.05).

جدول ب. مقايسه ضريب زخم ماكروسكويى ناشى از آسيرين در كروههياى تيمار ونسبت بهبودى زخم

\begin{tabular}{|c|c|c|c|}
\hline نسبت بهبودى در برابر آب مقطر & نسبت بهبودى در مقابل امبرازول & ضريب زخم Ulcer Index & Loog \\
\hline$\% 91 / \Delta r$ & $\% / 9 \cdot / r \Lambda$ & $r / 9 \Delta$ & شيرين بيان \\
\hline$\%$ \% $/ 1 / r$ & $\%$ \% $1 / \wedge \Delta$ & $r / r$ & شيرينبيان و كتيرا \\
\hline$\% .99$ & - & $r \cdot / q Y$ & اميرازول (كنترل مثبت) \\
\hline$\cdot$ & - & Tr/Th & آب مقطر (كنترل منفى) \\
\hline
\end{tabular}

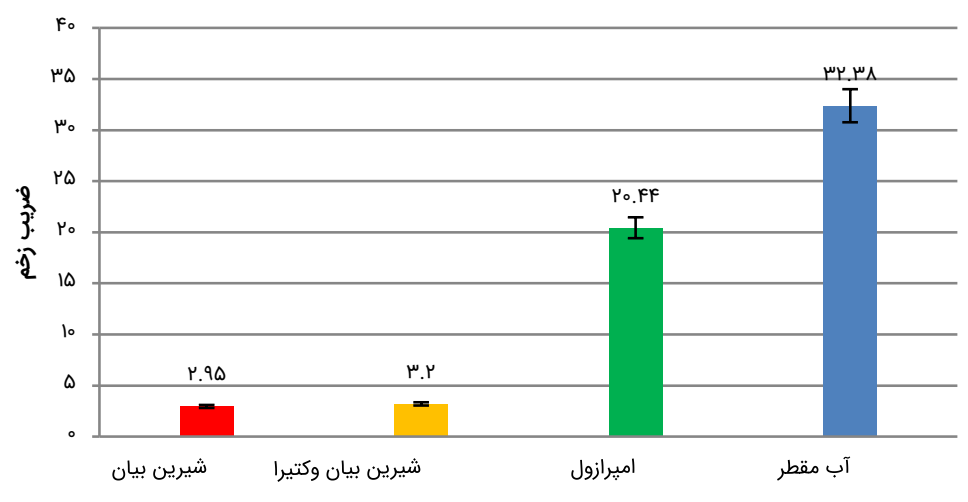

نمودار r. نمودارمقايسه ضريب زخم در كروههاى تيمار در مقايسه با كروههاى شاهد (p0.01) 


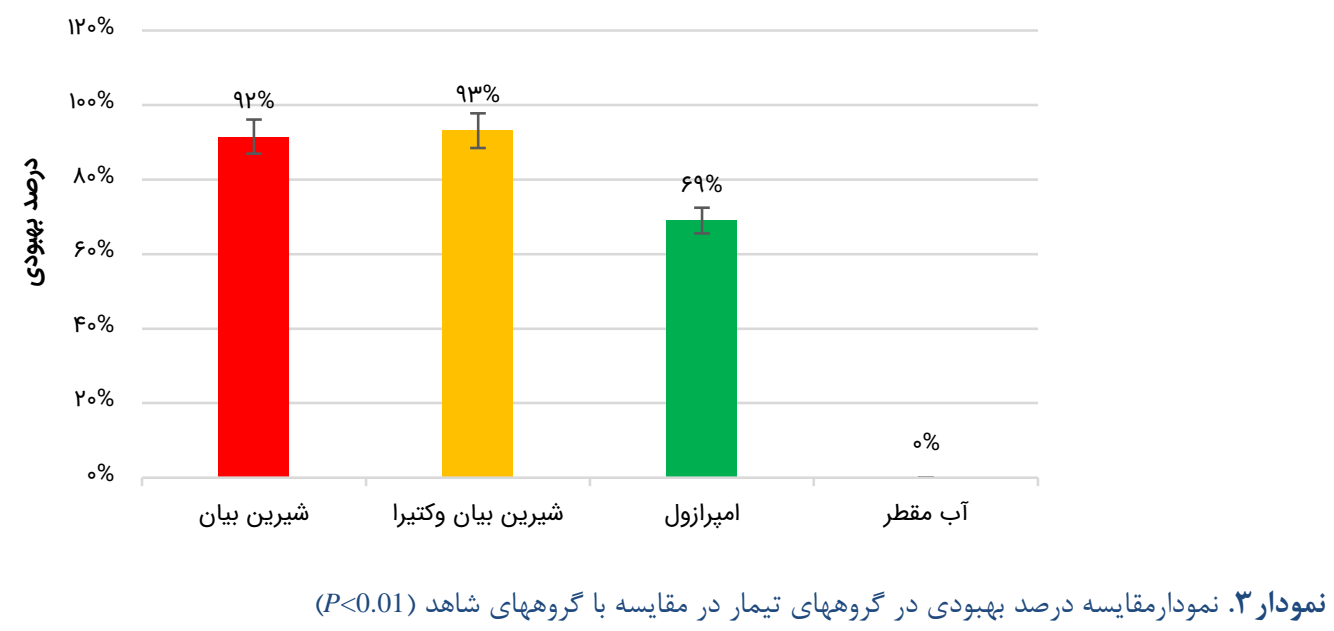

ناحيه زير مخاطى و مخاطى ديده مى شود كه نشانه وجود التهابات

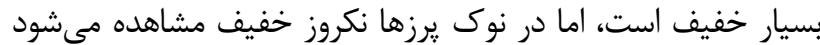
كه در مقايسه با كروه شاهد مثبت، اثر هم افزايى كتيرا وشيرينبيان

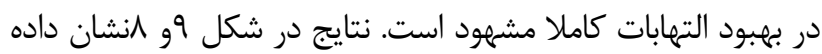
شده است.
درگروه تيمارشيرينبيان و كتيرا، تغييرات ياتولوزيك در معده كاملا محو شده و الكوى هيستوياتولوزيك كاملا نرمال بوده كه اثر هم افزايى كتيرا و شيرينبيان را نشان مىدهد و در روده تراوش خفيف سلولهاى ايمنى در ناحيه مخاطى و زير مخاطى ديده مى اشيود و

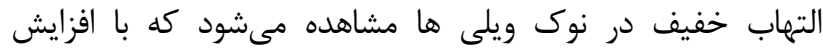
سلولهاى يلى مورفونكلئر همراه است. انتشارخفيف لنفوسيتها در هابر
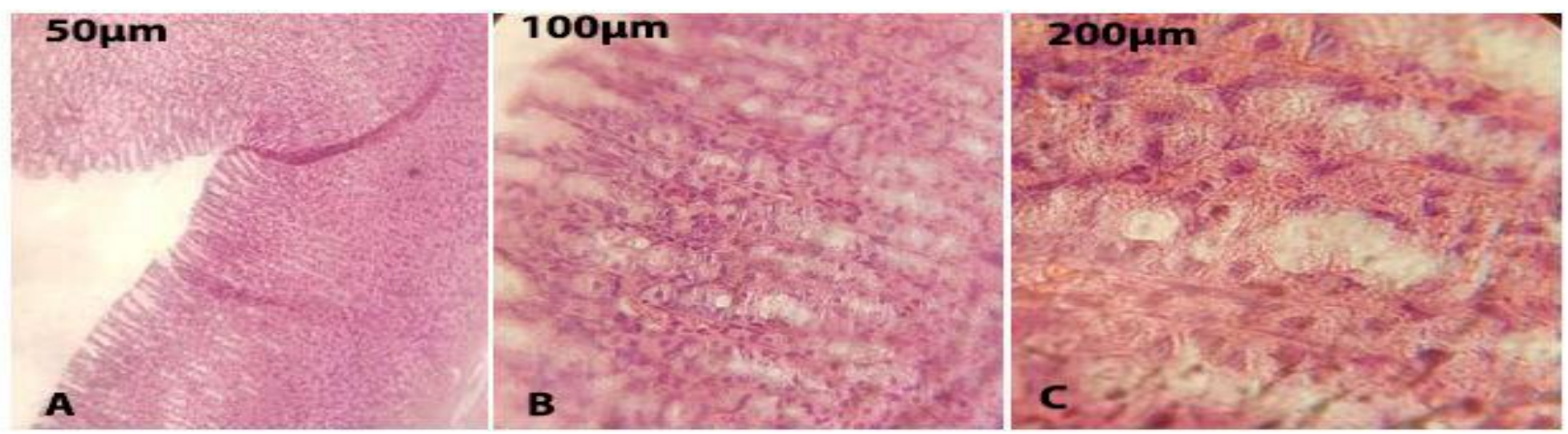

شكل ^.تاثير زخم زدايى شيرينبيان و كتيرا بر روى بافت معده. با توجه به شكل بالا الكَوى هيستوياتولوزى كاملانرمال شده است.
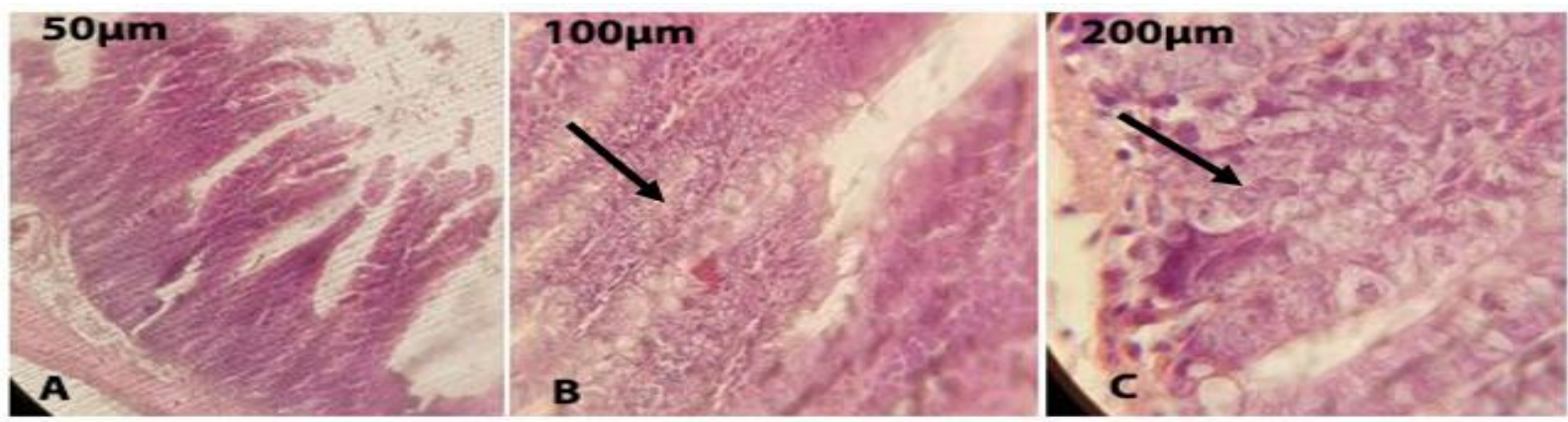

شكل 9. تاثير زخم زدايى شير ين بيان و كتيرا بر روى بافت روده . التهاب و نكروز خفيف تعدادى سلول لنفوسيتى (PMN) همجنان بعد از مصرف شيرينبيان و كتيرا در محل تورم ويلى مشاهده مئشود. تصاتير زدئ. 
عدم بهبود صد درصد زخم معده با اميرازول است. نتايج تاثير

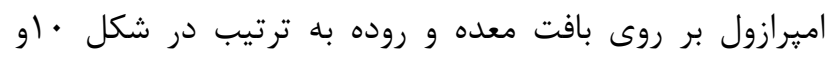
ا النشان داده شده است.

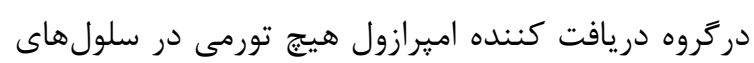

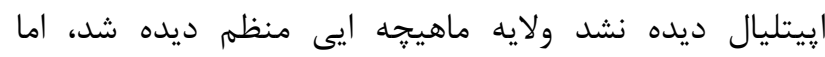
لنفوسيتها همجنان در لايه زير مخاطى ديده مي شئ شوند كه نشانه
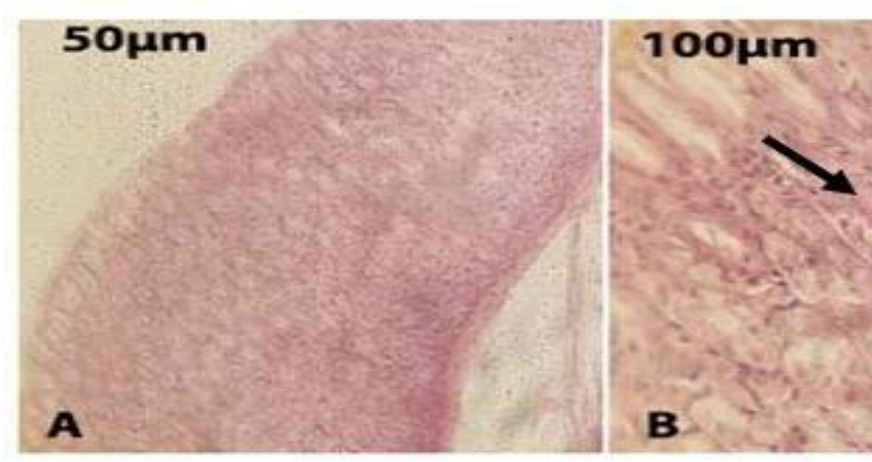

شكل •ا. تصوير ميكروسكويى اززخه بِاتولوزيك در معده در كروه تيمار با امير ازول (فلش: ارتشاح خفيف لنفوسيتى را نشان مى دهد كه حاكى از عدم بهبود صد در صد در
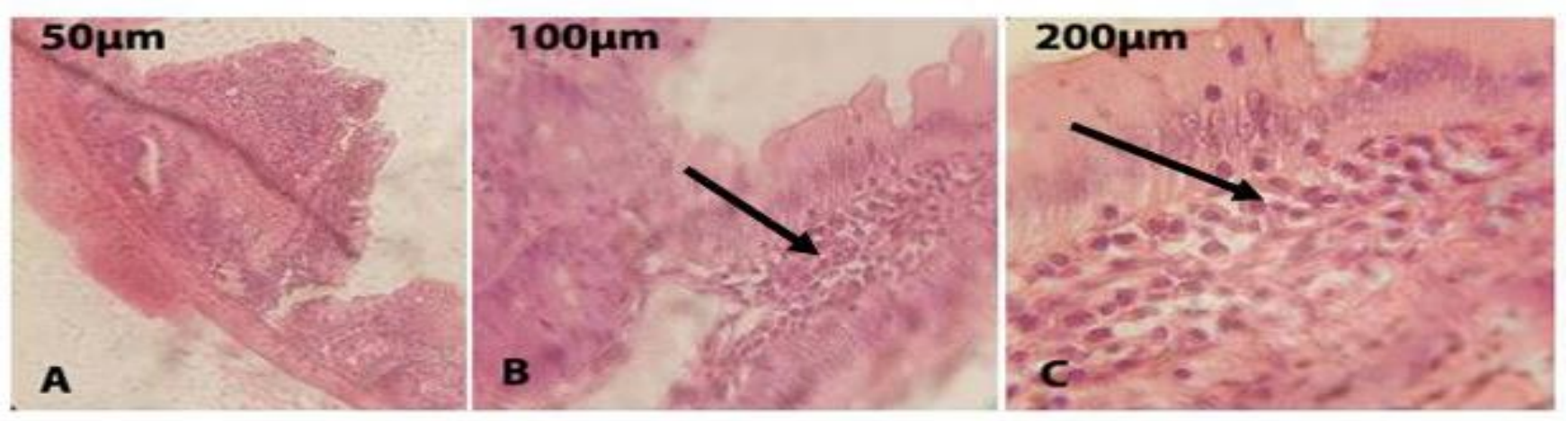

شكل ال. تصوير ميكروسكويى ازخخم باتولوزيك در روده در كروه تيمار با اميرازول(فلش:ارتشاح زياد نوتروفيلى همراه با اتساع ركمها در يرزهاى روده را نشان مى دهد كه

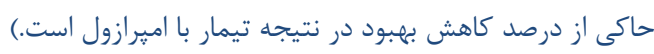

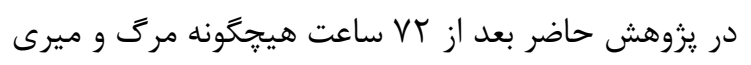
يس از تزريق دوزهاى مختلف عصاره ايجاد نشد، يس إِ احتمالاً

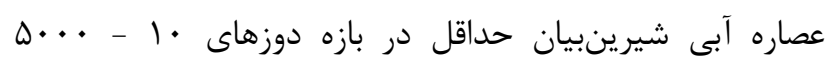

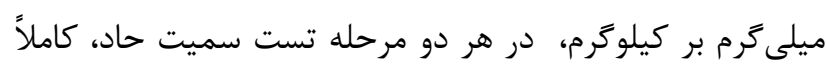

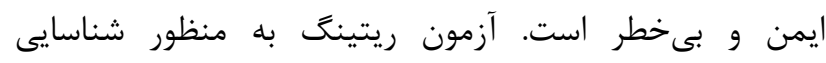
مكانيسمهاى محيطى استفاده شده و اسيد استيك در اين اين آزمون

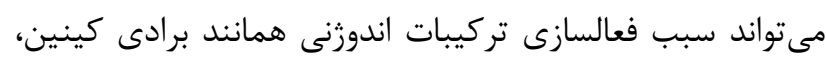

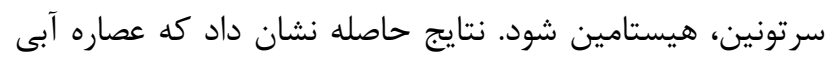

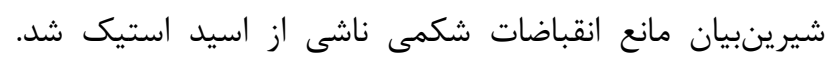

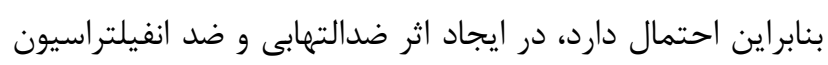

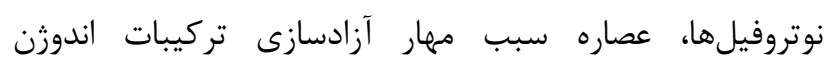

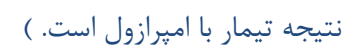

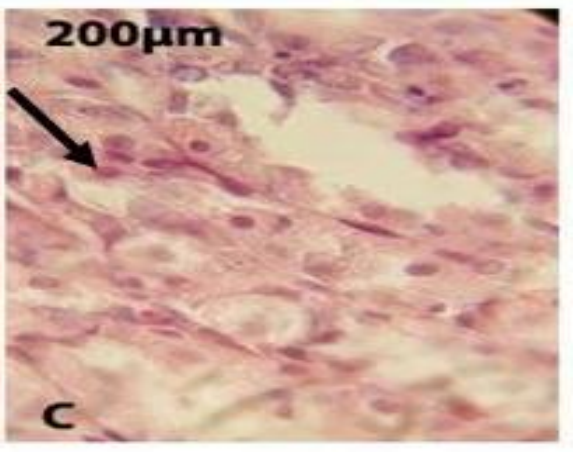


به صورت كاواز استفاده شده است و به طور مستقيم با سلولهاى روده و معده مرتبط بوده است. شايد بتوان كفت كه در تغييرات بافتى وكاهش اينفلتراسيون سلولهاى التهابى در مكان موثر بوده

است كه البته نيازمند تحقيقات وسيعترى مىباشد (rا).

در بررسىهاى ميكروبيولوزى نتايج حاصل در مورد كروهى

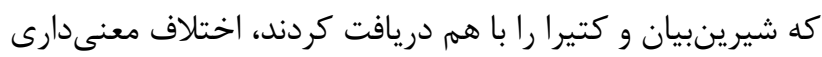
با كروهى كه فقط شيرينبيان دريافت كردند، وجود نداشت (ه • • • اما در بررسى هاى ياتولوزيك اين اختلاف معنى دار بود و اين (P>

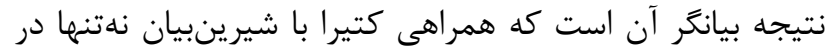

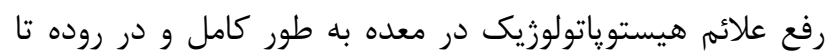
حدى تاثير گذار است، بلكه بر طبق مقالات مى تواند عوارض ناشى از مصرف شيرينبيان مثل افزايش فشار خون را پايين بياورد كه

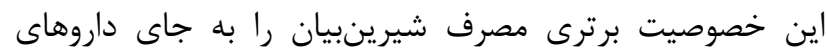

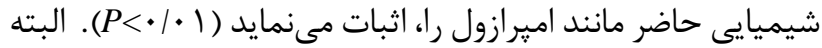
اثرهم افزايى كتيرا و شيرينبيان، با استفاده از دوزهاى مختلف، بايد در تحقيقى ديخر بر رسى شود.

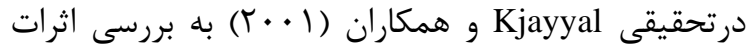
عصارههاى آبى بادرنجوبه، اسيبريس، بابونه، زيره سياه، نعناع،

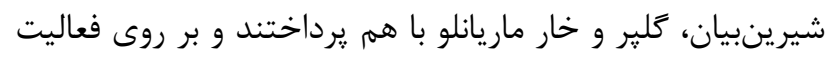
ضد زخم اين عصارهها به صورت تركيبى در دستگكاه توارش كار كردند. نتايج فعاليت ضد زخم عصارهها از نظر بافت شناسى تاييد

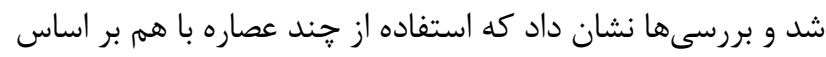
دوز مصرفى مىتواند به كاهش ميزان اسيد و افزايش ترشح موسين،

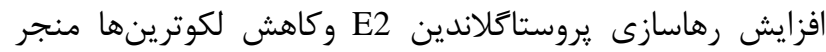

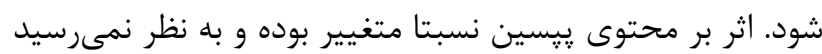

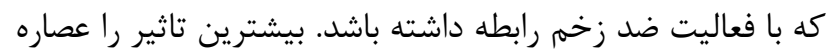
آبى كياه شيرينبيان و اسيبريس در دوز • اميلى گرم بر كيلوكرم

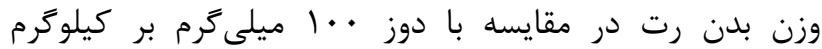

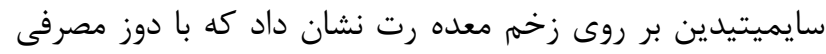
عصاره آبى در اين تحقيق اختلاف دارد. در اين تحقيق از عصاره

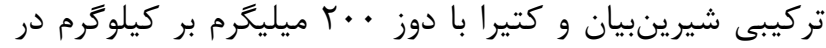
مقايسه با داروى اميرازول استفاده شده است. اختلاف ميزان دوز

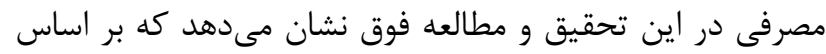
نوع مواد موثره موجود در هر كياه حتى با كارايى يكسان، دوز مصرفى متفاوت است و اثر سينرزيسم عصارههاى گياهى بر اساس دوز آنها بسيار متفاوت است و حتفى حتى عوارض احتمالى مصرف
(متابوليتهاى اسيد آراشيدونيك) شده و اثرات تسكينى آن با

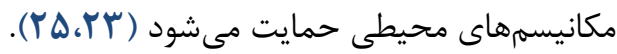

نتايج تحقيق حاضر نشان داد كه عصاره آبى ريشه كياه

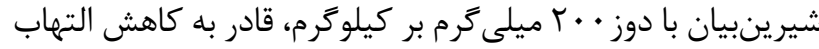

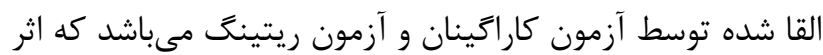
ضد التهابى آن قابل مقايسه با دكزامتازون نبوده است. كياه شيرينبيان داراى تركيبات كليسريزين، ليكوريسيدين، سايونين، كليسريزيك اسيد، آتوكسى كليسريزيك، اسيد لاكتيك است كه در توافق با منابع حاضر احتمال داده مىشود كه ماده فنولى إنى به نائ نام

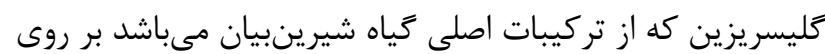
التهاب ناشى از زخم معده در موش هاى صحر ايى اثر مثبت داشته

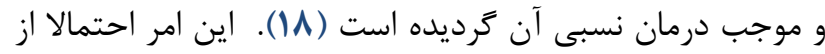

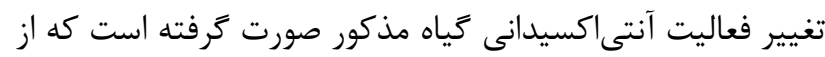
طريق مهار يروتئين كيناز C و فسفوليياز A و فسفودى استراز و

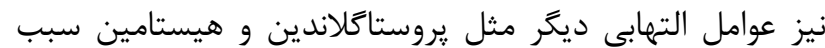

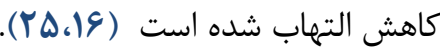

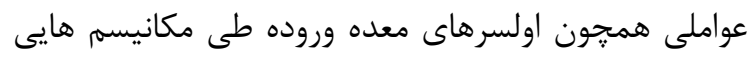
سبب افزايش كلسيم و راديكال آزاد مى گردد و طى فرايندى منجر

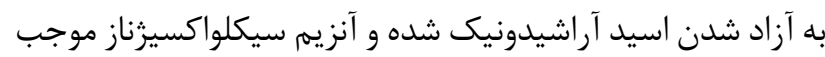

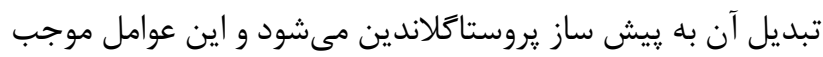

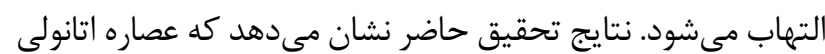
شيرينبيان باعث مهار التهاب در آزمون رايتينگ و كاراتِآينان

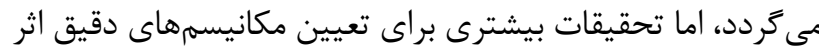

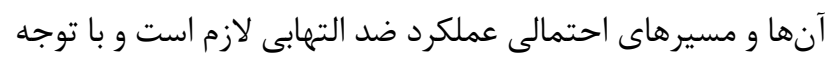
به خواص ذكر شده به همعان استفاده از شيرينبيان توصيه

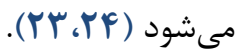

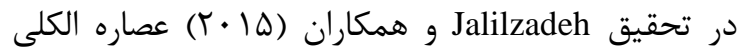

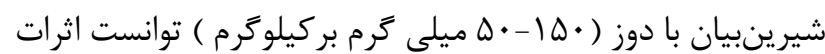

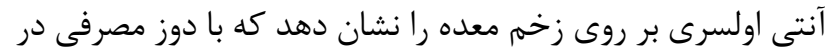

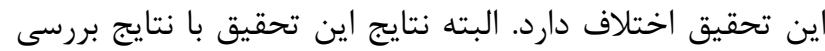

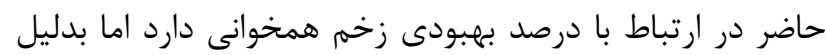
استفاده از عصاره اتانولى در تحقيق Jalilzadeh در زمينه ميزان كاهش اثرات التهابى با نتايج اين تحقيق اختلاف دارد، زيرا در اين إنان

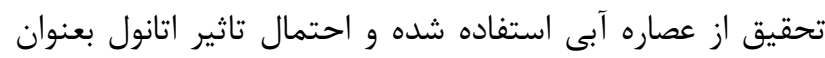

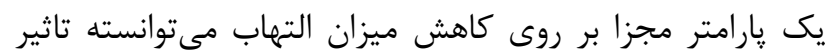

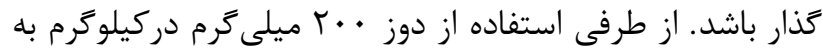
صورت تزريق صفاقى بوده است ولى در اين تحقيق دوز مصرفى الى دئى 


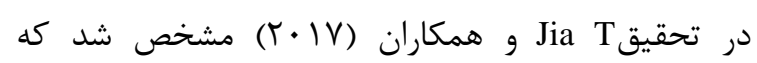

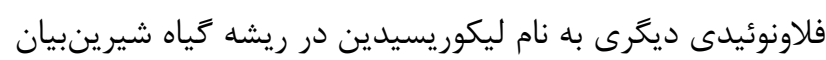

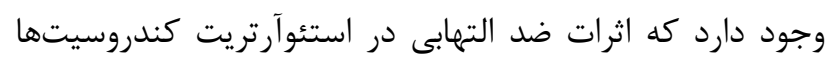

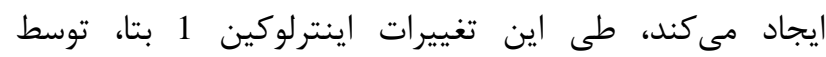

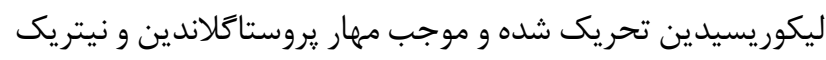

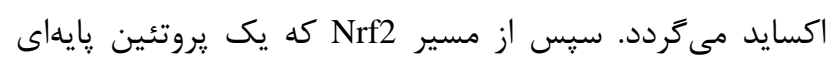

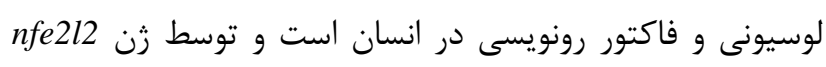

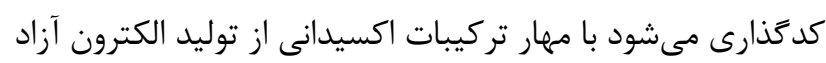

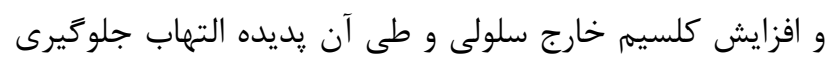

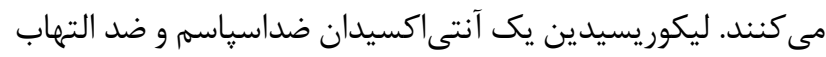

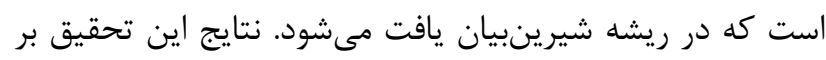

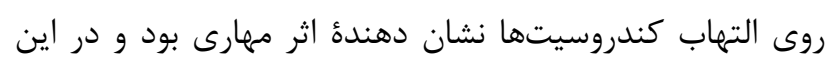

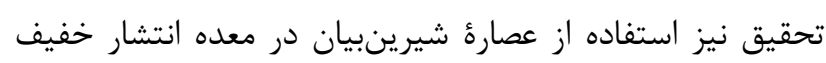

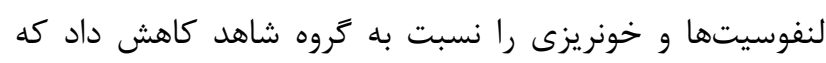

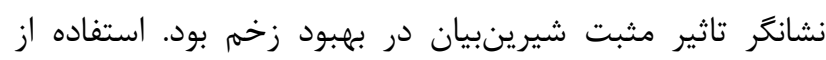

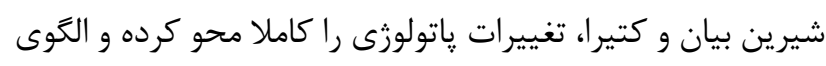

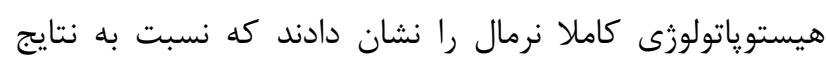

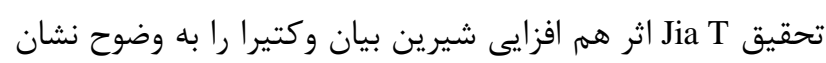

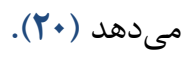

\section{نتيجه}

اگر خه اثر آنتى اولسرى عصاره شيرينبيان را مىتوان به تركيبات شيميايى موجود در عصاره كياه مربوط دانست، انسي، با توجيه

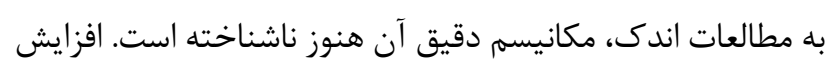

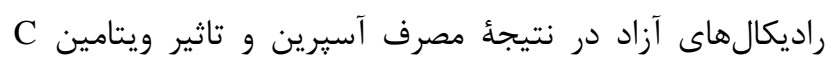

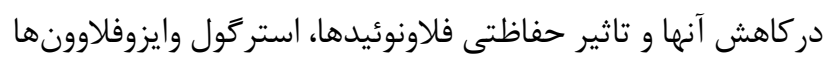

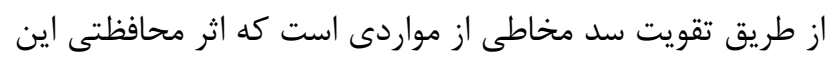

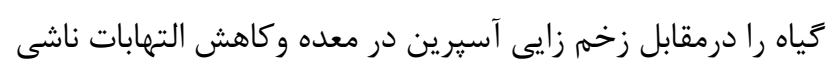

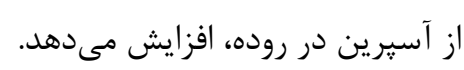

ارزان بودن، بومى بودن و در دسترس بودن اين كياهان از

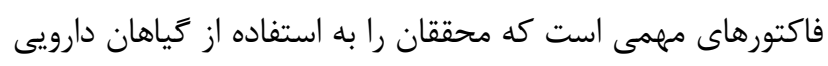

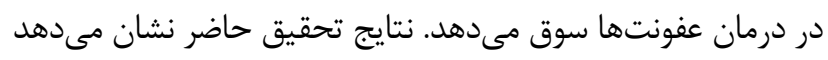

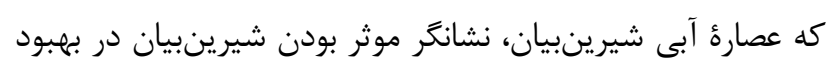

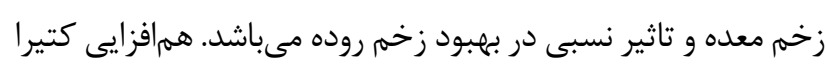

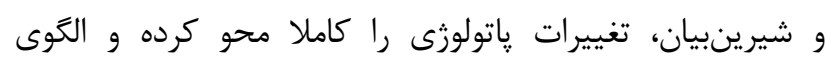

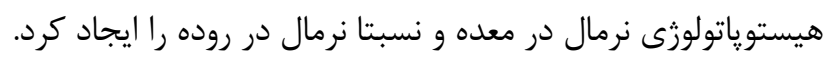

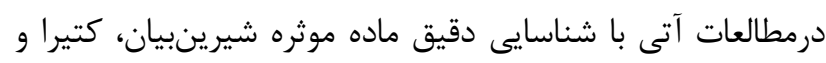

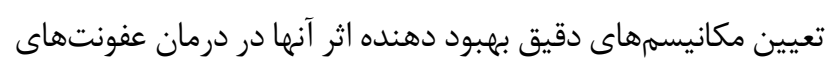

عصارهها به صورت تركيبى بر اساس دوز تغيير مىنمايد كه نيازمند

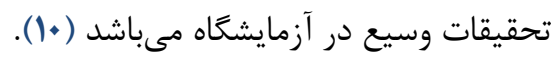

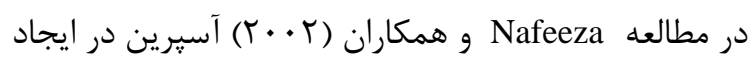

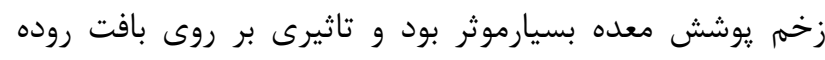

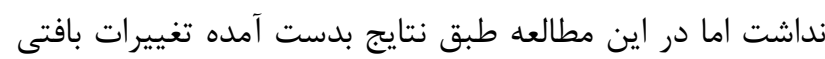

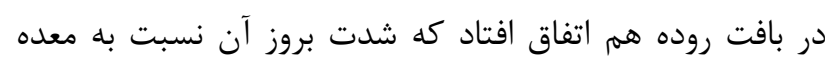

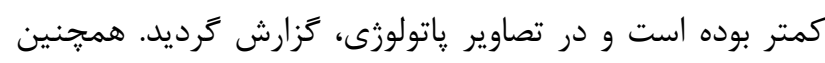

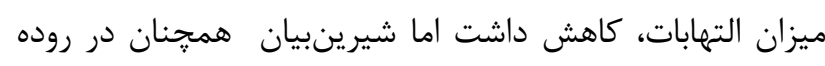

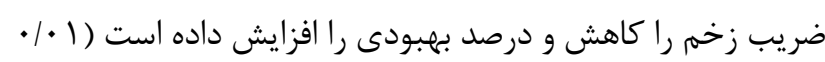

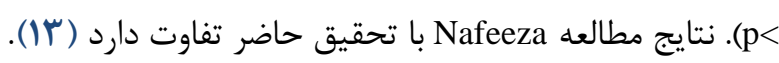
اتيولوزى زخمم معده هنوز مورد بحث است، اما عدم تعادل بين

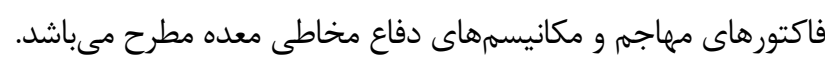

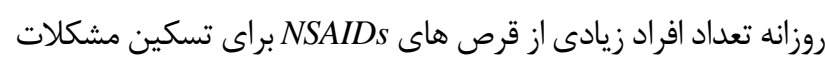

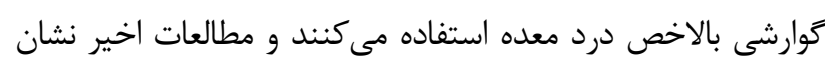

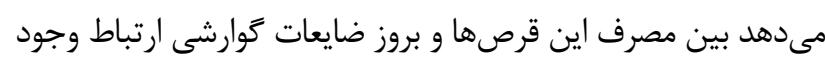

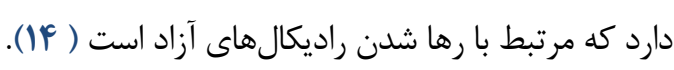
برخى از گياهان دارويى مىتوانند بر عملكرد دستخاه گوارشى

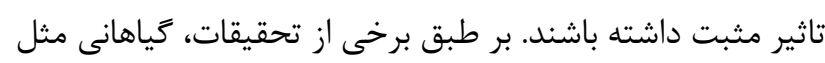

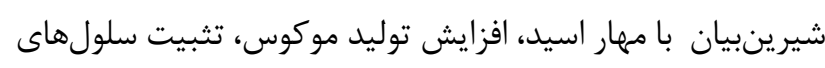

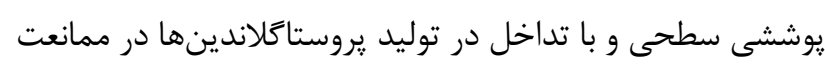

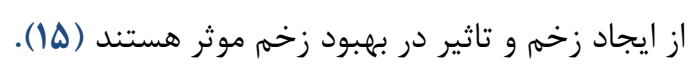

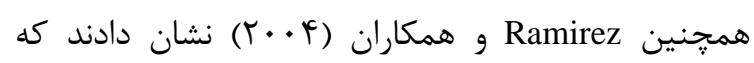

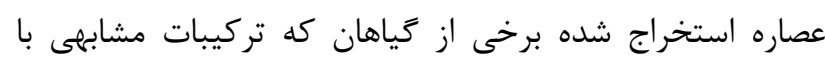

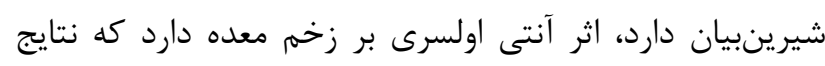

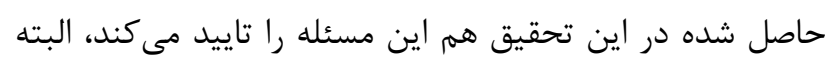

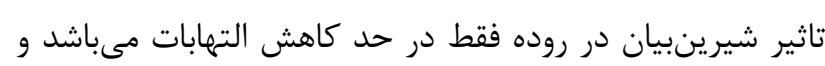

بهبود كامل درضايعات روده حاصل نشده است (9) (1). كياه شيرينبيان Glycyrrhiza glabra از تيره سبزى آساها است

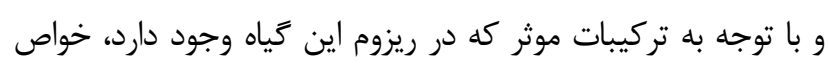

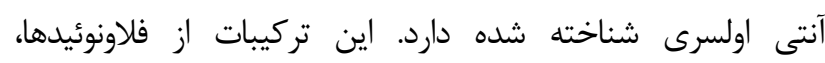

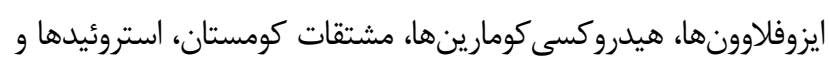

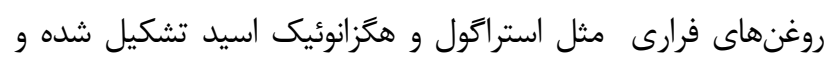

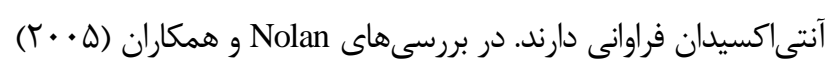

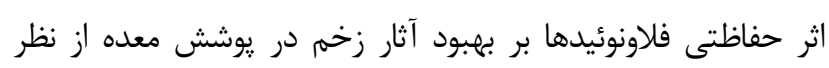
ياتولوزى نشان داده شد كه با مطالعه حاضر همخوانى دارد (IV). 


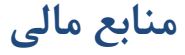

$$
\begin{aligned}
& \text { تامين منابع مالى اين تحقيق به طور كامل بعهله نويسندكان } \\
& \text { بوده است. }
\end{aligned}
$$

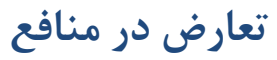

$$
\begin{aligned}
& \text { اين مقاله يزوهشى مستقل است كه بدون حمايت مالى }
\end{aligned}
$$

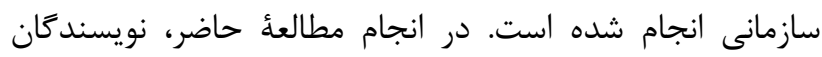

$$
\begin{aligned}
& \text { هيجَّونه تضاد منافعى نداشتهاند. }
\end{aligned}
$$

$$
\begin{aligned}
& \text { كوارشى، مسيرهاى احتمالى عملكرد ضد التهابى مشخص خواهد }
\end{aligned}
$$

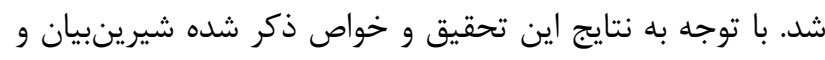

$$
\begin{aligned}
& \text { عدم عوارض جانبى بر روى دستكاههاى بدن استفاده از شيرين بيان } \\
& \text { و كتيرا بر مبناى دستور متخصصين توصيه مىشود. } \\
& \text { سياسگزارى } \\
& \text { اين تحقيق، طرح يزوهشى دبيرستان استعدادهاى درخشان }
\end{aligned}
$$

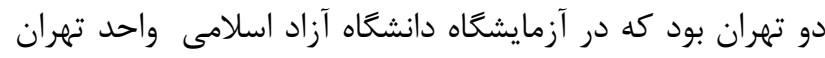

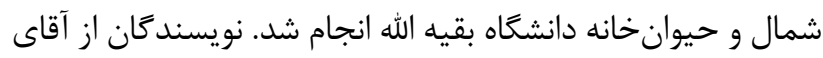

$$
\begin{aligned}
& \text { دكتر برخوردارى (مسئول حيوانخانه) و آقاى دكتر امينى كمال }
\end{aligned}
$$

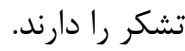

\section{Referance}

1. Khanahmadi M, Naghdi Badi H, Akhondzadeh S, Khalighi - Sigaroodi F, Mehrafarin A, Shahriari S, Hajiaghaee R. A Review on Medicinal Plant of Glycyrrhiza glabra L. J Med Plants. 2013; 2(46):1-12.

2. Khoshnam SE, Farzaneh M, Valipour M, Bahaoddini A, Valipour A. Review of the phytochemical, pharmacological and physiological properties of Licorice (Glycyrrhizaglabra). J Clin Excel. 2015; 4(1): 56-71.

3. Kazemi A, Nowrozi H, Oral vitamin E effect on Aspirininduced gastric ulcers by oral and parenteral administration in rats. J Urmia Univ Med Sci. 2015; 26(7): 542-549.

4. 6 (4) :237-244. 5- Mesut S, Thaer H, Betul O. Comparative effectiveness of Glycyrrhiza glabra vs.omeprazole and misoprostol for the treatment of aspirin-induced gastric ulcers. Afr. J. Pharm. Pharmacol. 2009

5. Shahabi Nezhad M, Rahmani MR, Khaksari Hadad M, Sepehri GH.R, Mahmoudi M, Karim Ghasemi E. The Effect of Licorice Root Extract on Blood Sugar Level in Streptozotocin-Induced Diabetic Rats. J. Rafsanjan Univ. Med. Sci. 2007; 6

6. (4) :237-244. 5- Mesut S, Thaer H, Betul O. Comparative effectiveness of Glycyrrhiza glabra vs.omeprazole and misoprostol for the treatment of aspirin-induced gastric ulcers. Afr. J. Pharm. Pharmacol. 2009; 3(12):615-620.

7. Nugroho AE, Wijayanti A, Mutmainah M, Susilowati R, Rahmawati N.Gastroprotective Effect of Combination of Hot Water Extracts of Licorice (Glycyrrhiza glabra), Pulasari Stem Bark (Alyxia reinwardtii), and Sembung Leaf (Blumea balsamifera) Against Aspirin-Induced Gastric Ulcer Model Rats. J Evid Based Complementary Altern $\quad$ Med. .2016; 21(4):77-84. [DOI:10.1177/2156587216637469] [PMID]

8. Farzaneh N, Faraz M, Mehran H-R, Kowsar B. Large scale screening of commonly used Iranian traditional medicinal plants against urease activity. DARU J. Pharm. Sci. 2012; 20(72):2-9. [DOI:10.1186/2008-2231-20-72] [PMID] [PMCID]

9. Khoshnam SE, Farzaneh M, Bahaoddini AA, Savary F, Shabani S. Evaluation of the Interactive Effects of Glycyrrhiza Glabra Hydroalcoholic Extract and LNAME Drug on Blood Pressure and Heart Rate of Male Rats. J Babol Univ Med Sci. 2016; 18(6);59-65. 9- Byron C, Kenneth W M. Gastrointestinal ulcers, the role of aspirin, and clinical outcomes: pathobiology, diagnosis, and treatment. J Multidiscip Healthcare. 2014; 7: 137-146.

10. Khayyal MT, El-Ghazaly MA, Kenawy SA, Seif-el-Nasr M, Mahran LG, Kafafi YA, Okpanyi SN. Arzneimittelforschung. Effect of Some Gastrointestinally Acting Plant Extracts and their Combination. 2001; 51(7): 545-553. [DOI:10.1055/s-0031-1300078] [PMID]

11. Jiang H, Paul K, Whelton, MD, Brian V, Michael J, Klag MD, Aspirin and Risk of Hemorrhagic Stroke, A Metaanalysis of Randomized Controlled Trials. JAMA. 1998; 280(22):1930-1935. [DOI:10.1001/jama.280.22.1930] [PMID]

12. Jalilzadeh-amin Gh, Najarnezhad V, Anassori E, Mostafavi M, Keshipour H. Antiulcer properties of Glycyrrhiza glabra L. extract on experimental models of gastric ulcer in mice. Iran J Pharm Res. 2015;14(4): 11631170 .

13. Nafeeza MI, Fauzee AM, Kamiah J, Gapor MT. Comparative effects of a tocotrienol-rich fraction and tocopherol in aspirin-induced gastric lesions in rats. Asia Pacific Journal of Clinical Nutrition banner. Asia Pac J Clin Nutr.2002;11(4): 309-313. [DOI:10.1046/j.14406047.2002.00298.x] [PMID]

14. Langman MJ, Weil J, Wainwright $\mathrm{P}$, Lawson $\mathrm{DH}$, Rawlins MD, Logan RF, Murphy M, Vessey MP, ColinJones DG. Risks of bleeding peptic ulcer associated with individual non-steroidal anti-inflammatory drugs. Lancet. 
1994; 343( 8905) : 1075-1078. [DOI:10.1016/S01406736(94)90185-6]

15. Bafna PA, Balaraman R. Anti-ulcer and anti-oxidant activity of Pepticare, a herbomineral formulation. Phytomedicine. 2005;12(4):264-270. [DOI:10.1016/j.phymed.2003.12.009] [PMID]

16. Ramirez RO, Roa CC Jr. The gastroprotective effect of tannins extracted from duhat (Syzygium cumini Skeels) bark on $\mathrm{HCl} /$ ethanol-induced gastric mucosal injury in Sprague-Dawley rats. Clin Hemorheol Microcirc. 2003;29(3-4):253-61.

17. Linda LN, Ronald GN. Future of Natural Products from Plants in the Struggle with Emerging Diseases: Case of Food-Borne Pathogens and Leishmaniasis. J Herbs Spices Med Plants. 2005;11(1-2):161-190. [DOI:10.1300/J044v11n01_06]

18. McAlindon ME, Muller AF, Filipowicz B, Hawkey CJ. Effect of allopurinol, sulphasalazine, and vitamin $\mathrm{C}$ on aspirin-induced gastroduodenal injury in human volunteers.Gut. $\quad 1996 ; 38(4)$ : 518-524. [DOI:10.1136/gut.38.4.518] [PMID] [PMCID]

19. Ghayedi N, Bahaoddini A, Khoshnam SE, Gholampour F, Khosravi AR, Moein MR. Evaluation of the effect of hydro-alcoholic extract of GlycyrrhizaGlabra rhizome on the isolated colon contractions of male rats.J of University Sadoughi Shahid of Medical Sciences.2016;24(7):576586.

20. Jia T, Qiao J, Guan D, Chen T. Anti-inflammatory effects of licochalcone a on il-1 $\beta$-stimulated human osteoarthritis chondrocytes. J. Inflammation. 2017;40(6): 1894-1902. [DOI:10.1007/s10753-017-0630-5] [PMID]

21. Lorke DA. New approach to acute toxicity testing. Archives of Toxicol. 1983; 54 (4): 275 - 87. [DOI:10.1007/BF01234480] [PMID]

22. Golshani Y, Mohammadi S. Antinociceptive and Acute Toxicity Effects of Erigeron acer L. In Adult Male Rats.2016;16(62):1393-96.

23. Bentley GA, Newton SH, Starr J. Evidence for an action of morphine and the enkephalins on sensory nerve endings in the mouse peritoneum. British J. Pharmacol. 1981; 73: 325 - 32. [DOI:10.1111/j.1476-5381.1981.tb10425.x] [PMID] [PMCID]

24. Sharifi Soltani M, Eidi A, Haeri Rouhani SA. AntiInflammatory Effect of Glycyrrhizaglabra Ethanolic Extract. In AdultMale NMRI Mice.1397;11(3):15-25.

25. Larypoor M, Bayat M, Zuhair MH, Akhavan Sepahy A, Amanlou M. Evaluation of The Number of CD4+ CD25+ FoxP3+ Treg Cells in Normal Mice Exposed to AFB1 and Treated with Aged Garlic Extract. Cell journal.2013;15(1):37-44. 